\title{
Experimental diagenesis: insights into aragonite to calcite transformation of Arctica islandica shells by hydrothermal treatment
}

\author{
Laura A. Casella ${ }^{1}$, Erika Griesshaber ${ }^{1}$, Xiaofei Yin ${ }^{1}$, Andreas Ziegler ${ }^{2}$, Vasileios Mavromatis ${ }^{3,4}$, Dirk Müller ${ }^{1}$, \\ Ann-Christine Ritter ${ }^{5}$, Dorothee Hippler ${ }^{3}$, Elizabeth M. Harper ${ }^{6}$, Martin Dietzel ${ }^{3}$, Adrian Immenhauser ${ }^{5}$, \\ Bernd R. Schöne ${ }^{7}$, Lucia Angiolini ${ }^{8}$, and Wolfgang W. Schmahl ${ }^{1}$ \\ ${ }^{1}$ Department of Earth and Environmental Sciences and GeoBioCenter, Ludwig-Maximilians-Universität München, \\ 80333 Munich, Germany \\ ${ }^{2}$ Central Facility for Electron Microscopy, University of Ulm, 89081 Ulm, Germany \\ ${ }^{3}$ Institute of Applied Geosciences, Graz University of Technology, Graz, 8010, Austria \\ ${ }^{4}$ Géosciences Environnement Toulouse (GET), CNRS, 31400 Toulouse, France \\ ${ }^{5}$ Institute for Geology, Mineralogy and Geophysics, Ruhr University Bochum, 44801 Bochum, Germany \\ ${ }^{6}$ Department of Earth Sciences, University of Cambridge, Cambridge, CB2 3EQ, UK \\ ${ }^{7}$ Institute of Geosciences, University of Mainz, 55128 Mainz, Germany \\ ${ }^{8}$ Dipartimento di Scienze della Terra “A. Desio”, Università degli Studi di Milano, 20133 Milan, Italy \\ Correspondence to: Laura A. Casella (laura.casella@1rz.uni-muenchen.de)
}

Received: 24 August 2016 - Discussion started: 26 September 2016

Revised: 2 February 2017 - Accepted: 23 February 2017 - Published: 24 March 2017

\begin{abstract}
Biomineralised hard parts form the most important physical fossil record of past environmental conditions. However, living organisms are not in thermodynamic equilibrium with their environment and create local chemical compartments within their bodies where physiologic processes such as biomineralisation take place. In generating their mineralised hard parts, most marine invertebrates produce metastable aragonite rather than the stable polymorph of $\mathrm{CaCO}_{3}$, calcite. After death of the organism the physiological conditions, which were present during biomineralisation, are not sustained any further and the system moves toward inorganic equilibrium with the surrounding inorganic geological system. Thus, during diagenesis the original biogenic structure of aragonitic tissue disappears and is replaced by inorganic structural features.

In order to understand the diagenetic replacement of biogenic aragonite to non-biogenic calcite, we subjected Arctica islandica mollusc shells to hydrothermal alteration experiments. Experimental conditions were between 100 and $175^{\circ} \mathrm{C}$, with the main focus on 100 and $175^{\circ} \mathrm{C}$, reaction durations between 1 and 84 days, and alteration fluids simu-
\end{abstract}

lating meteoric and burial waters, respectively. Detailed microstructural and geochemical data were collected for samples altered at $100^{\circ} \mathrm{C}$ (and at $0.1 \mathrm{MPa}$ pressure) for 28 days and for samples altered at $175^{\circ} \mathrm{C}$ (and at $0.9 \mathrm{MPa}$ pressure) for 7 and 84 days. During hydrothermal alteration at $100^{\circ} \mathrm{C}$ for 28 days most but not the entire biopolymer matrix was destroyed, while shell aragonite and its characteristic microstructure was largely preserved. In all experiments up to $174{ }^{\circ} \mathrm{C}$, there are no signs of a replacement reaction of shell aragonite to calcite in X-ray diffraction bulk analysis. At $175^{\circ} \mathrm{C}$ the replacement reaction started after a dormant time of 4 days, and the original shell microstructure was almost completely overprinted by the aragonite to calcite replacement reaction after 10 days. Newly formed calcite nucleated at locations which were in contact with the fluid, at the shell surface, in the open pore system, and along growth lines. In the experiments with fluids simulating meteoric water, calcite crystals reached sizes up to $200 \mu \mathrm{m}$, while in the experiments with Mg-containing fluids the calcite crystals reached sizes up to $1 \mathrm{~mm}$ after 7 days of alteration. Aragonite is metastable at all applied conditions. Only a small bulk thermodynamic 
driving force exists for the transition to calcite. We attribute the sluggish replacement reaction to the inhibition of calcite nucleation in the temperature window from ca. 50 to ca. $170^{\circ} \mathrm{C}$ or, additionally, to the presence of magnesium. Correspondingly, in $\mathrm{Mg}^{2+}$-bearing solutions the newly formed calcite crystals are larger than in $\mathrm{Mg}^{2+}$-free solutions. Overall, the aragonite-calcite transition occurs via an interfacecoupled dissolution-reprecipitation mechanism, which preserves morphologies down to the sub-micrometre scale and induces porosity in the newly formed phase. The absence of aragonite replacement by calcite at temperatures lower than $175^{\circ} \mathrm{C}$ contributes to explaining why aragonitic or bimineralic shells and skeletons have a good potential of preservation and a complete fossil record.

\section{Introduction}

The skeletons of marine calcifiers are considered highresolution archives of proxies to understand the evolution of the Earth system. They are widespread in the fossil record and are sensitive to changes in seawater composition (e.g. Brand et al., 2003; Parkinson et al., 2005; Schöne and Surge, 2012; Brocas et al., 2013). However, diagenetic alteration of fossil biogenic carbonates is a significant obstacle in understanding past climate dynamics (Grossmann et al., 1993; Richardson et al., 2001; Immenhauser et al., 2005; Korte et al., 2005). Despite more than a century of research on carbonate diagenesis, many of the controlling processes are still only understood in a qualitative manner (Brand and Veizer, 1980, 1981; Swart, 2015). One of the main problems is that diagenetically altered carbonates occur as the product of a complex alteration pathway with an unknown number of intermediate steps and controlling factors (Immenhauser et al., 2015; Swart, 2015; Ullmann and Korte, 2015). Motivated by the lack of quantitative data on rates and products of marine, meteoric, and burial diagenesis, we performed laboratorybased alteration experiments with Arctica islandica shells with the aim to obtain time series data sets. The bivalve $A$. islandica has been studied in several scientific disciplines, e.g. biology (Morton, 2011; Oeschger and Storey, 1993; Taylor, 1976; Strahl et al., 2011). Arctica islandica has also gained profound attention in palaeoclimatology due to its long lifespan and its use as a high-resolution long-term archive (e. g. Marchitto et al., 2000; Schöne, 2004; Schöne et al., 2005a, b, 2013; Wanamaker et al., 2008, 2011; Butler et al., 2009, 2013; Karney et al., 2012). From a long-term perspective, $A$. islandica plays an important role in palaeontology, not only as a Neogene palaeoecological and palaeoclimatic archive (e.g. Marchitto et al., 2000; Schöne, 2004; Schöne et al., 2005a, b, 2013; Wanamaker et al., 2008, 2011; Butler et al., 2009, 2013; Karney et al., 2012; Crippa et al., 2016) but also as a biostratigraphic tool. Formerly considered a marker for the Pliocene-Pleistocene boundary (Raffi, 1986) in the
Mediterranean region, its first appearance is now regarded as an indicator of the Gelasian-Calabrian (early Pleistocene) boundary, around 1.7 Ma (Crippa and Raineri, 2015). The potential of this species for palaeontology is strictly dependent on its preservation and thus the dynamics of diagenetic shell alteration.

At ambient conditions calcite is the stable and, thus, the least soluble polymorphic phase of $\mathrm{CaCO}_{3}$ (Plummer and Mackenzie, 1974; Plummer and Busenberg, 1982; Sass et al., 1983; Walter and Morse, 1984; Bischoff et al., 1987, 1993; Redfern et al., 1989; Navrotsky, 2004; Morse et al., 2007; Gebauer et al., 2008, Gebauer and Cölfen, 2011; Radha and Navrotsky, 2013), while at higher pressures aragonite forms the stable calcium carbonate polymorph (Redfern et al., 1989; Radha and Navrotsky, 2013). Accordingly, calcite crystallises from aqueous solutions below ca. $50^{\circ} \mathrm{C}$ (if no calcite-inhibitors are present). However, even in pure $\mathrm{Ca}^{2+} / \mathrm{HCO}_{3}^{-}$solutions, at temperatures above ca. $50^{\circ} \mathrm{C}$ metastable aragonite rather than calcite is obtained (Kitano et al., 1962; Taft, 1967; Ogino et al., 1987). There is no sharp tipping point but rather a gradual change of fraction of the precipitating phases (Ogino et al., 1987; Balthasar and Cusack, 2015). Furthermore, inhibitors of calcite nucleation and/or growth decrease the temperature of this regime shift in precipitation even further; in marine and diagenetic environments the most important inorganic inhibitor is $\mathrm{Mg}^{2+}$ (Kitano et al., 1972; Katz, 1973; Berner, 1975; Morse et al., 1997; Choudens-Sanchez, 2009; Radha et al., 2010; Balthasar and Cusack, 2015; Sun et al., 2015).

The replacement reaction of aragonite to calcite in aqueous systems was investigated by Bischoff and Fyfe (1968), Metzger and Barnard (1986), Yoshioka et al. (1968), Bischoff (1969), Kitano et al. (1972), Katz (1973), Oomiri et al. (1987), and more recently by Perdikouri et al. (2011, 2013). It was recognised by Fyfe and Bischoff (1965) that the aragonite to calcite replacement reaction in aqueous environments occurs by dissolution and reprecipitation reactions. Except for Metzger and Banard (1968) and Perdikouri et al. (2011, 2013), most authors have used powdered samples of geological or powdered synthetic aragonite. For these powdered samples, they claim a rapid replacement reaction of aragonite to calcite within hours or very few days at temperatures of ca. $100^{\circ} \mathrm{C}$ or above, depending on temperature and the $\mathrm{Mg}$ content of the solution.

Metzger and Banard (1968) and Perdikouri et al. (2011, 2013) investigated aragonite blocks or single crystals and report that temperatures in excess of $160-170^{\circ} \mathrm{C}$ are required to transform the aragonite to calcite within a couple of days, whereas below $160^{\circ} \mathrm{C}$ aragonite remains present over many weeks.

The present study describes first experimental data of the replacement reaction of BIOGENIC aragonite to nonbiogenic calcite and investigates the kinetics of the replacement reaction of aragonite to calcite in shell material, geochemistry, nano- and microstructure alteration, and crystal- 
lographic texture variation. During biomineralisation, living organisms create local micro-environments for physiological generation of their composite hard tissues. After the death of the organism, all tissues become altered by equilibration with the surrounding environment - part of the complex set of processes called diagenesis. Thus, as diagenetic alteration proceeds, the species-specific fingerprint of the biogenic structure disappears and is replaced by inorganic features. Despite the fact that the evolutionary line of $A$. islandica dates back to the Jurassic (Casey, 1952), only a limited number of studies have dealt with $A$. islandica specimens due to the thermodynamically unstable nature of their aragonitic shells. The aim of the present paper is to describe analysis-based detailed microstructural, geochemical, phase, and texture data observed in the experimental simulation of diagenesis by hydrothermal treatment of modern A. islandica shell samples. With this study, we gain quantitative insight into processes that take place along pathways from early marine pore water diagenesis to the pervasive recrystallisation under burial conditions. The targets of the present study are the analysis of microstructural features, the preservation of the organic matrix in the shell, and the kinetics of the replacement reaction of aragonite to calcite as investigated by X-ray diffraction, scanning electron microscopy (SEM), and crystallographic microanalysis determined by electron backscatter diffraction (EBSD). Element maps of $\mathrm{Cl}, \mathrm{Mg}, \mathrm{Na}$, and $\mathrm{Sr}$ were determined by electron probe micro-analysis (EPMA).

\section{Materials and methods}

\subsection{Test materials}

For this study, shells of $A$. islandica were collected from the recent shell middens of a fishing company in northern Iceland and from Loch Etive waters in Scotland. On average, shells were between 8 and $10 \mathrm{~cm}$ in size and represent adult specimens. Major morphological features of the shell of Arctica islandica are displayed in Fig. A1; see also Schöne et al. (2013).

\subsection{Methods applied}

\subsubsection{Organic matrix preparation by selective etching}

To image the organic matrix in modern reference and hydrothermally altered shell samples as well as the mineral part in the reference specimens, i.e. geologic, and non-biological aragonite, shell or mineral pieces were mounted on $3 \mathrm{~mm}$ thick cylindrical aluminium rods using super glue. The samples were first cut using a Leica Ultracut ultramicrotome with glass knives to obtain plane surfaces within the material. The cut pieces were then polished with a diamond knife (Diatome) by stepwise removal of material in a series of 20 sections with successively decreasing thicknesses (90, $70,40,20,10$ and $5 \mathrm{~nm}$; each step was repeated 15 times) as reported in Fabritius et al. (2005). The polished samples were etched for $180 \mathrm{~s}$ using 0.1 M HEPES ( $\mathrm{pH}=6.5)$ containing $2.5 \%$ glutaraldehyde as a fixation solution. The etching procedure was followed by dehydration in $100 \%$ isopropanol three times for $10 \mathrm{~s}$ each, before the specimens were critical-point-dried in a BAL-TEC CPD 030 (Liechtenstein). The dried samples were rotary-coated with $3 \mathrm{~nm}$ of platinum and imaged using a Hitachi S5200 field emission-secondary electron microscope (FE-SEM) at $4 \mathrm{kV}$.

\subsubsection{Hard tissue characterisation methods}

For FE-SEM and EBSD analyses, $5 \mathrm{~mm} \times 5 \mathrm{~mm}$ thick pieces were cut out of the shell and embedded in epoxy resin. The surface of the embedded samples was subjected to several sequential mechanical grinding and polishing steps down to a grain size of $1 \mu \mathrm{m}$. The final step was etch polishing with colloidal alumina (particle size $\sim 0.06 \mu \mathrm{m}$ ) in a vibratory polisher. For EBSD analysis, the samples were coated with 4 $6 \mathrm{~nm}$ of carbon, and for SEM visualisation and electron probe micro analysis (EPMA) with $15 \mathrm{~nm}$. EBSD measurements were carried out on JEOL JSM 6400 field emission SEM, equipped with a Nordlys EBSD detector. The SEM was operated at $20 \mathrm{kV}$ and measurements were indexed with the CHANNEL 5 HKL software (Schmidt and Olesen, 1989; Randle and Engler, 2000). Information obtained from EBSD measurements is presented as band contrast images and as colour-coded crystal orientation maps with corresponding pole figures.

The EBSD band contrast gives the signal strength of the EBSD-Kikuchi diffraction pattern and is displayed as a greyscale component of EBSD scanning maps. The strength of the EBSD signal is high when a crystal is detected (bright), while it is weak or absent when a polymer such as organic matter is scanned (dark/black).

Co-orientation statistics are derived from pole figures obtained by EBSD scans and are given by the MUD (multiple of uniform (random) distribution) value. The MUD value is a measure of crystal co-orientation (texture sharpness) in the scanned area. High MUD values indicate a high crystal coorientation (in this study calcite), whereas low MUD values reflect a low to random co-orientation.

In order to trace the infiltration and percolation of fluids into and through the shells, pristine and hydrothermally altered shell samples were scanned with EPMA (Goetz et al., 2014). Chemical data were obtained by using a CAMECA SX100 EPMA system equipped with a $\mathrm{LaB}_{6}$ cathode. An accelerating voltage of $15 \mathrm{keV}$ at a current of $40 \mathrm{nA}$ were used as operative settings. All elements were analysed with wavelength-dispersive X-ray spectrometers. The $\mathrm{Sr}-\mathrm{K} \alpha, \mathrm{Mg}$ $\mathrm{K} \alpha$, and $\mathrm{Na}-\mathrm{K} \alpha$ were measured on a TAP (thallium acid phthalate) crystal and $\mathrm{Cl} \mathrm{K} \alpha$ measured on an LPET (large pentaerythritol) crystal. L $\alpha$ emission lines of $\mathrm{Mn}$ and Fe were detected with a LLIF (large lithium fluoride) crystal. A step size in the range of $1-2 \mu \mathrm{m}$ with a dwell time of $150 \mathrm{~ms}$ was 

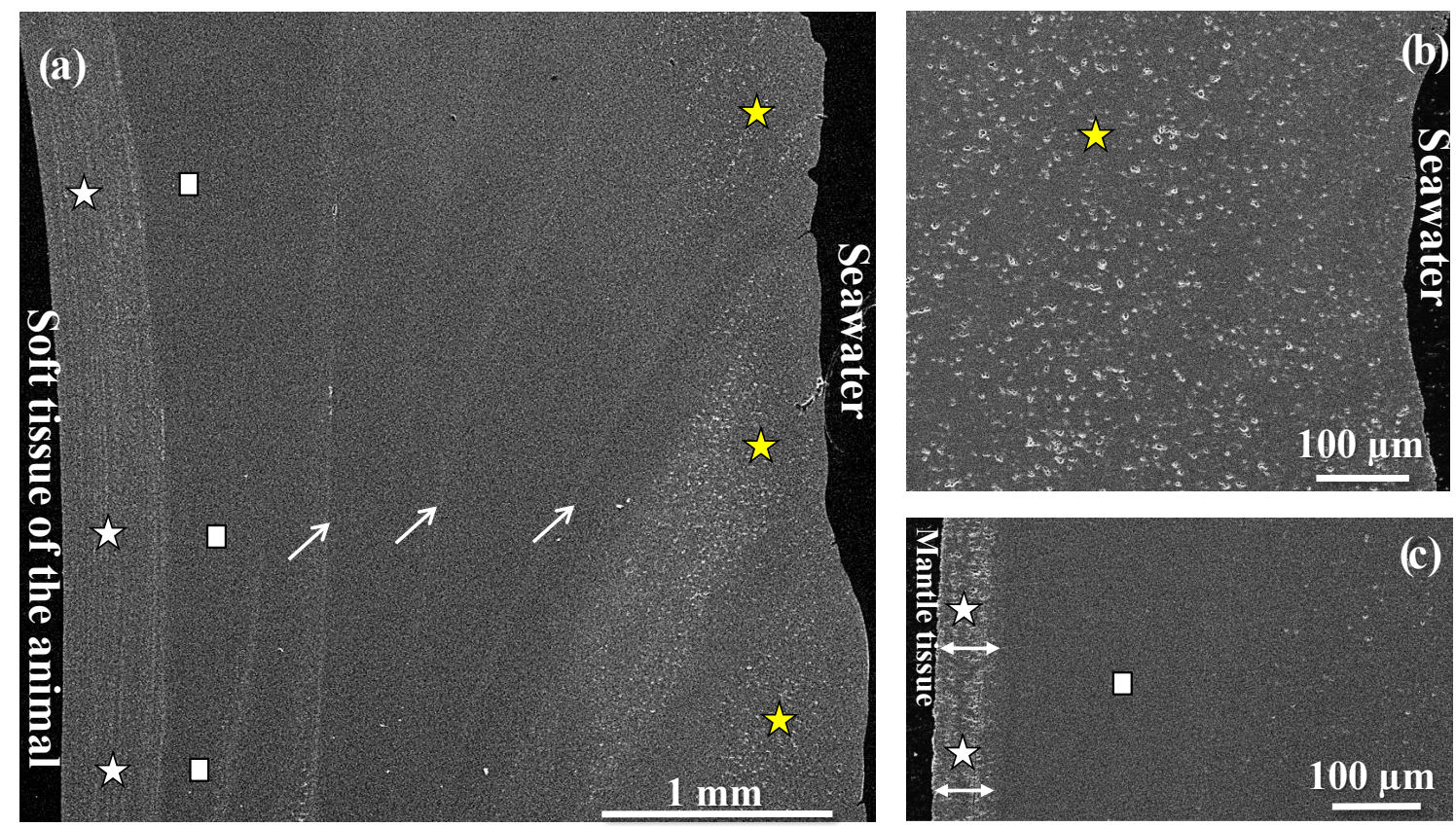

Figure 1. SEM image showing ultrastructure characteristics of the shell of modern Arctica islandica (a), its high porosity in shell layers facing seawater (yellow stars in $\mathbf{a}, \mathbf{b}$ ) and the denser shell portions (white stars in a, c) close to the soft tissue of the animal. The innermost shell portions contain elongated pores (white stars in $\mathbf{c}$ ) with the long axis of the pores oriented perpendicular to the inner surface of the shell (white arrows in c). Highly dense shell parts are also present (white rectangles in a, c), in which pore density and size is very low and where minute aragonite crystals are closely packed. White arrows in (a) indicate the location of growth lines.

chosen for the element mappings. Celestine (Sr), dolomite $(\mathrm{Ca}, \mathrm{Mg})$, ilmenite $(\mathrm{Mn})$, apatite $(\mathrm{P})$, albite $(\mathrm{Na})$, benitoite $(\mathrm{Ba})$, vanadinite $(\mathrm{Cl})$, and hematite $(\mathrm{Fe})$ were used as standard materials. Matrix correction was carried out using the PAP procedure (Pouchou and Pichoir, 1984).

\subsubsection{Alteration experiments}

Hydrothermal alteration experiments mimicked burial diagenetic (and meteoric) alteration of recent $A$. islandica under controlled laboratory conditions. Chemical and experimental information on hydrothermal experiments utilised in the present study are given in Table 1. All fluids were spiked with ${ }^{18} \mathrm{O}$-depleted oxygen in order to trace fluid-solid exchange reactions and isotopic studies investigated by Ritter et al. (2017).

Details of the experimental protocol can be found in Riechelmann et al. (2016). Briefly, pieces $(2 \mathrm{~cm} \times 1 \mathrm{~cm})$ of recent $A$. islandica specimens were placed in a PTFE liner together with $25 \mathrm{~mL}$ of either the meteoric $(10 \mathrm{mM} \mathrm{NaCl}$ aqueous solution) or burial fluid ( $100 \mathrm{mM} \mathrm{NaCl}+10 \mathrm{mM} \mathrm{MgCl} 2$ aqueous solution) and sealed with a PTFE lid. Each of the PTFE liners was placed in a stainless steel autoclave, sealed and kept in the oven at temperatures of 100, 125, 150 and $175^{\circ} \mathrm{C}$ for different periods of time ranging between 1 day and 84 days (see Table 1, Fig. A11 and Table 2 for experiments; main focus was on 100 and $175^{\circ} \mathrm{C}$ ). Obviously, this temperature regime is far beyond natural meteoric diagenetic environments (Lavoie and Bourque, 1993) but is typical for the burial realm (Heydari, 1997). Nevertheless, elevated fluid temperatures were applied to meteoric experiments, too, as reaction rates under surface conditions are too slow for experimental approaches. After the selected time period, an autoclave was removed from the oven, cooled down to room temperature and then opened. The aqueous fluid that had passed through a $0.2 \mu \mathrm{m}$ cellulose acetate filter was subjected to further chemical and isotopic analyses. Recovered solids were dried at $40^{\circ} \mathrm{C}$ overnight.

\subsubsection{X-ray diffraction analysis}

$\mathrm{X}$-ray diffraction analysis of pristine and hydrothermally treated samples was performed with $\mathrm{Mo}-\mathrm{K}_{\alpha} 1$ radiation in transmission geometry and with $\mathrm{Cu}-\mathrm{K}_{\alpha} 1$ radiation in reflection geometry on a General Electric Inspection Technologies XRD3003 X-ray diffractometer with an incident-beam Ge111 focussing monochromator and a Meteor positionsensitive detector. The diffractograms were analysed by Rietveld analysis with the software package FULLPROF (Rodriguez-Caravajal, 2001) using the aragonite structure data of Jarosch and Heger (1986) and calcite structure data of Markgraf and Reeder (1985). 
Table 1. Detailed conditions used in hydrothermal alteration experiments of modern Arctica islandica. Major and minor element chemical data of pristine Arctica islandica aragonite and the calcite obtained after treatment are given in Table A1.

\begin{tabular}{|c|c|c|c|c|c|c|c|c|}
\hline Sample name & $\begin{array}{l}\text { Fluid } \\
\text { type }\end{array}$ & $\begin{array}{r}\mathrm{NaCl} \\
\text { content } \\
(\mathrm{mM})\end{array}$ & $\begin{array}{r}\mathrm{MgCl}_{2} \\
\text { content } \\
(\mathrm{mM})\end{array}$ & $\begin{array}{r}\text { Temperature } \\
\left({ }^{\circ} \mathrm{C}\right)\end{array}$ & $\begin{array}{l}\text { Experimental } \\
\text { time }\end{array}$ & $\begin{array}{r}\text { Alkalinity } \\
(\mathrm{mM})\end{array}$ & $\mathrm{pH}$ & $\begin{array}{r}\mathrm{Mg} \text { content of } \\
\text { fluid after } \\
\text { experiment } \\
\left(\mathrm{mg} \mathrm{L}^{-1}\right)\end{array}$ \\
\hline CHA-M-040 AI21 B2 & meteoric & 10 & - & 100 & 28 days & 1.69 & 7.91 & 3 \\
\hline CHA-M-042 AI 23 B2 & meteoric & 10 & - & 175 & 7 days & 7.72 & - & 0 \\
\hline CHA-M-046 AI27 B1 & meteoric & 10 & - & 175 & 84 days & 10.75 & 7.78 & 1 \\
\hline CHA-M-043 AI24 B2 & burial & 100 & 10 & 100 & 28 days & 2.02 & 8.39 & 112 \\
\hline CHA-M-041 AI22 B2 & burial & 100 & 10 & 175 & 7 days & 9.96 & - & 84 \\
\hline CHA-M-046 AI 27 B2 & burial & 100 & 10 & 175 & 84 days & 6.99 & 7.51 & 165 \\
\hline CHA-M-044 AI29 L1 & burial & 100 & 10 & 125 & 1 day & & & \\
\hline CHA-M-044 AI29 L2 & burial & 100 & 10 & 125 & 14 days & & & \\
\hline CHA-M-044 AI29 L3 & burial & 100 & 10 & 150 & 2 days & & & \\
\hline CHA-M-044 AI26 L1 & burial & 100 & 10 & 175 & 1 day & & & \\
\hline CHA-M-044 AI20 L3 & burial & 100 & 10 & 175 & 3 days & & & \\
\hline CHA-M-044 AI28 L2 & burial & 100 & 10 & 175 & 4 days & & & \\
\hline CHA-M-044 AI28 L1 & burial & 100 & 10 & 175 & $41 / 4$ days & & & \\
\hline CHA-M-044 AI28 L2 & burial & 100 & 10 & 175 & $43 / 4$ days & & & \\
\hline CHA-M-044 AI20 L1 & burial & 100 & 10 & 175 & 5 days & & & \\
\hline CHA-M-044 AI20 L2 & burial & 100 & 10 & 175 & 6 days & & & \\
\hline
\end{tabular}

Table 2. Crystal co-orientation (texture) strength expressed as multiple of uniform (random) distribution (MUD) of modern and experimentally altered Arctica islandica shells. Ar: aragonite; Cc: calcite.

\begin{tabular}{|c|c|c|c|c|c|c|}
\hline Sample name & Fluid type & $\begin{array}{r}\text { Temperature } \\
\left({ }^{\circ} \mathrm{C}\right)\end{array}$ & $\begin{array}{l}\text { Experimental } \\
\text { time }\end{array}$ & $\begin{array}{r}\text { MUD value } \\
\text { of the } \\
\text { outermost } \\
\text { shell part }\end{array}$ & $\begin{array}{r}\text { MUD value } \\
\text { of the } \\
\text { central } \\
\text { shell part }\end{array}$ & $\begin{array}{r}\text { MUD value } \\
\text { of the } \\
\text { innermost } \\
\text { shell part }\end{array}$ \\
\hline Modern reference & - & - & - & 12 and $32 \mathrm{Ar}$ & $58 \mathrm{Ar}$ & $88 \mathrm{Ar}$ \\
\hline $\begin{array}{l}\text { Altered specimen } \\
C H A-M-040 A I 21 B 2\end{array}$ & meteoric & 100 & 28 days & $7 \mathrm{Ar}$ & $27 \mathrm{Ar}$ & $94 \mathrm{Ar}$ \\
\hline $\begin{array}{l}\text { Altered specimen } \\
C H A-M-043 \text { AI24 B2 }\end{array}$ & burial & 100 & 28 days & $4 \mathrm{Ar}$ & - & $99 \mathrm{Ar}$ \\
\hline $\begin{array}{l}\text { Altered specimen } \\
C H A-M-042 A I 23 B 2\end{array}$ & meteoric & 175 & 7 days & $18 \mathrm{Cc}$ & $15 \mathrm{Cc}$ & - \\
\hline $\begin{array}{l}\text { Altered specimen } \\
C H A-M-046 \text { AI27 BI }\end{array}$ & meteoric & 175 & 84 days & $25 \mathrm{Cc}$ & $32 \mathrm{Cc}$ & - \\
\hline $\begin{array}{l}\text { Altered specimen } \\
C H A-M-041 A I 22 B 2\end{array}$ & burial & 175 & 7 days & $36 \mathrm{Cc}$ & $90 \mathrm{Cc}$ & 80 and $81 \mathrm{Cc}$ \\
\hline $\begin{array}{l}\text { Altered specimen } \\
C H A-M-046 \text { AI } 27 \text { B2 }\end{array}$ & burial & 175 & 84 days & $64 \mathrm{Cc}$ & $62 \mathrm{Cc}$ & - \\
\hline
\end{tabular}

\section{Results}

\subsection{The shell ultrastructure of modern Arctica islandica}

Figures 1 to 5 show characteristic ultrastructural features of the shell of modern A. islandica. Images of the pristine shell are given in Figs. 1-3, while Figs. 4 and 5 present structural features of the hydrothermally altered shells. The valve of A. islandica is layered, with various shell parts showing different internal structural features (Fig. 1). The distribution patterns of porosity, pore sizes and the dimensions of basic aragonitic crystal units vary significantly along the cross section of the shell. The outer shell portion, indicated with yellow stars in Fig. 1a and b, consists of aragonite crystal units in the $5 \mu \mathrm{m}$ size range (Fig. 2a). This shell portion is highly porous (see the white dotted features in Fig. 1b), pore diameters range within a few micrometres (Fig. A2 in the Appendix). The inner shell portion, i.e. the part very close to the soft tissue of the animal (indicated with white rectangles in Fig. 1a, c), is dense and is composed of very few small arag- 

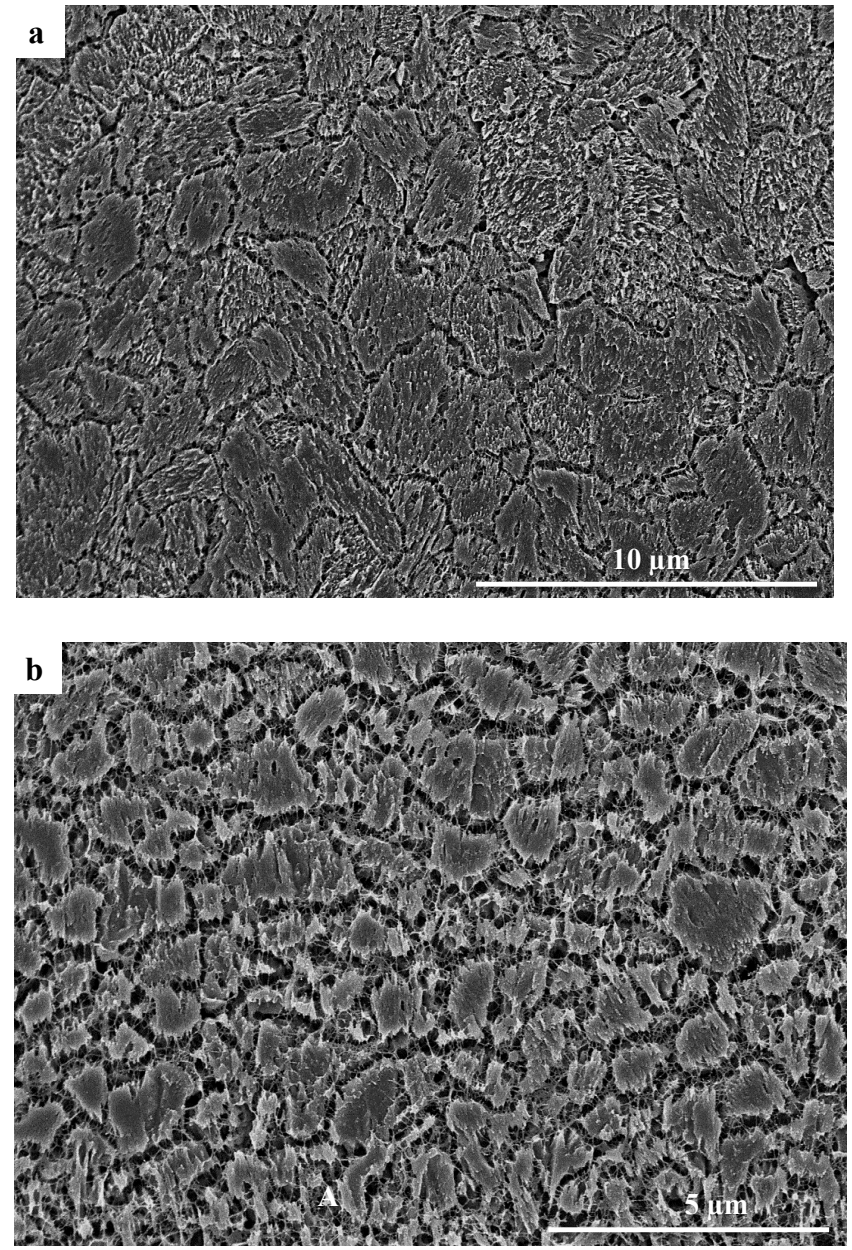

Figure 2. FE-SEM micrograph of microtome cut, microtomepolished, etched, and critical-point-dried surface of the shell of modern Arctica islandica: (a) the outer shell portion and (b) inner shell layer. Etching occurred for $180 \mathrm{~s}$ and was applied to remove aragonite in order to visualise the spatial distribution of (glutaraldehyde-stabilised) biopolymers within the shell. The outer shell portion consists of large and irregular mineral units, connected to each other and is infiltrated by a network of organic fibrils. The inner shell layers consist of significantly smaller mineral units. These are also interconnected by organic fibrils.

onite crystallites with pore sizes of less than $1 \mu \mathrm{m}$ (Fig. 2b). The dimension of pores in this shell region is in the 1 to $2 \mu \mathrm{m}$ range. However, the innermost shell layer, the layer that is in contact with the mantle tissue of the animal (white stars in Fig. 1a, c), contains large (up to $12 \mu \mathrm{m}$ diameter) and elongated pores that are oriented perpendicular to the rim of the shell (see white arrows in Fig. 1c). Growth lines are clearly visible in the cross section through the shell (white arrows in Fig. 1a) as thin layers are characterised by higher accumulations of organic material (this study and Richardson, 2001).

Figures 2 and 3 show, at increasing magnification, structural features of modern A. islandica shells that were made
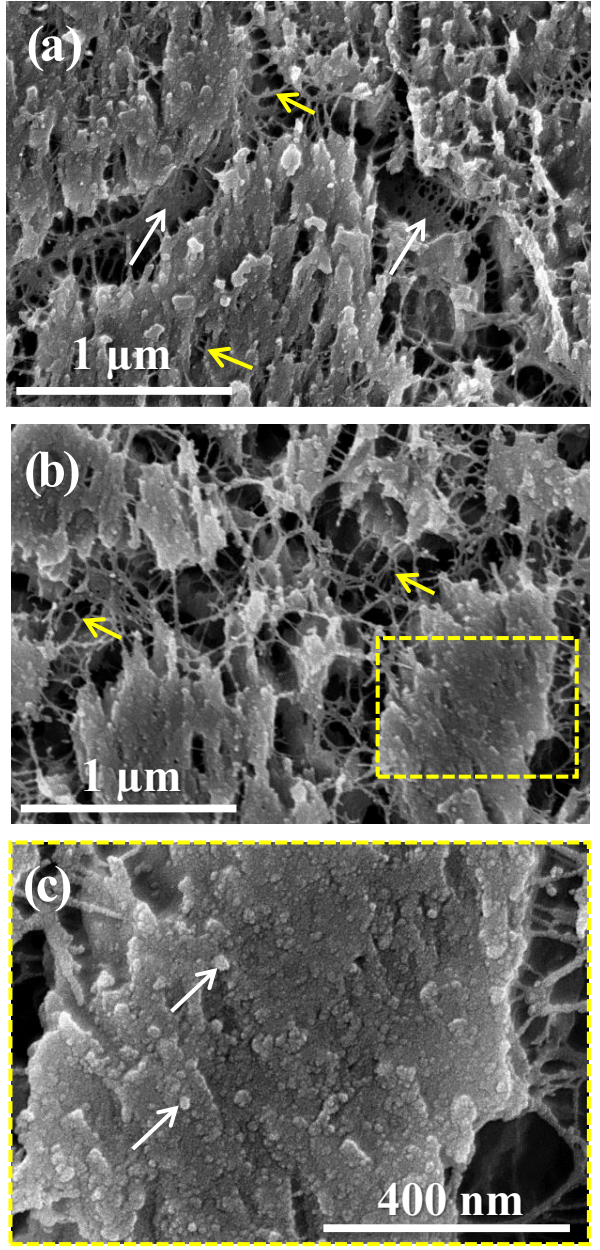

Figure 3. FE-SEM micrographs of cut, microtome-polished, etched, and critical-point-dried surfaces of modern Arctica islandica next to seawater (a) and close to the soft tissue of the animal $(\mathbf{b}, \mathbf{c})$. Etching occurred for $180 \mathrm{~s}$ and slightly removed aragonite in order to visualise the spatial distribution of (glutaraldehydestabilised) biopolymers within the shell. Readily visible are the nano-particulate consistency of the aragonitic hard tissue (white arrows in c) and the presence of biopolymer membranes (white arrows in $\mathbf{a}$ ) and fibrils (yellow arrows in $\mathbf{a}, \mathbf{b}$ ) between and within the mineral units.

visible by slight etching of the mineral and simultaneous chemical fixation of the organic matrix. Structural characteristics of the reference material (non-biological aragonite grown from solution), treated chemically in a similar way as the biogenic aragonite samples, are shown in the Appendix (Fig. A3). Figure 2a shows features that are characteristic of the outer shell layer, whereas Fig. 2b depicts internal characteristics of the tissue-adjacent side of the shell (the region marked by white rectangles in Fig. 1). Etching brings out the outlines of the aragonite grains, revealing the fabric of the biopolymer matrix within the hard tissue and its interlinkage with the mineral. The mineral units (crystals) in the outer 

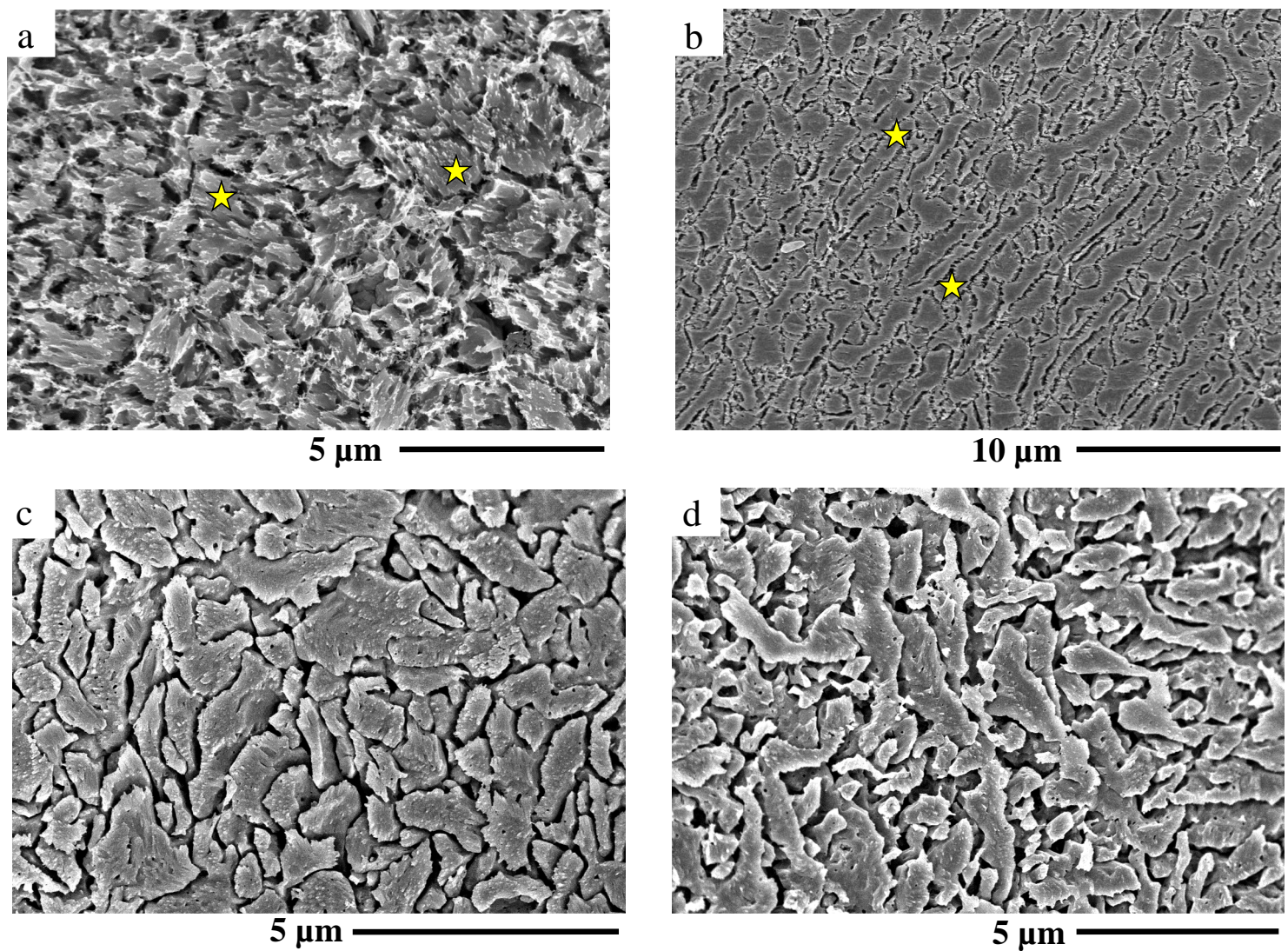

Figure 4. SEM micrographs of cut, microtome-polished, etched, and critical-point-dried surfaces of experimentally altered Arctica islandica shell materials: (a, c) outer shell layer and $(\mathbf{b}, \mathbf{d})$ inner shell layer. Etching occurred for $180 \mathrm{~s}$ and was applied for the visualisation of the spatial distribution of (glutaraldehyde-stabilised) biopolymers within the shell; $10 \mathrm{mM} \mathrm{NaCl}+10 \mathrm{mM} \mathrm{MgCl} 2$ aqueous solution (burial fluid) was used for alteration at $100^{\circ} \mathrm{C}$ for 28 days $(\mathbf{a}, \mathbf{b})$ and at $175^{\circ} \mathrm{C}$ for 7 days $(\mathbf{c}, \mathbf{d})$. Yellow stars in (a) and (b) indicate mineral units.

shell layer are highly irregular in shape with dimensions in the $1-5 \mu \mathrm{m}$ range (Fig. $2 \mathrm{a})$. In contrast, although the mineral units (crystals) in the dense layer of the shell also have irregular morphologies, they are of significantly smaller dimensions, mainly in the $1-2 \mu \mathrm{m}$ range and below (Fig. $2 b$ ). The predominant fabric of the organic matrix in the shell of $A$. islandica is a network of intracrystalline fibrils (Fig. 3, yellow arrows in Fig. 3a, b) that interconnect the mineral units across the grain boundaries. However, organic membranes are occasionally also present and surround the mineral units (white arrows in Fig. 3a). Like all other biological carbonate hard tissues, at the finest scale, the shell of A. islandica is composed of nanoparticles that are a few tens of nanometres in diameter (white arrows in Fig. 3c). In order to check the validity of nanoscale structural features observed in pristine Arctica islandica shells, we prepared non-biological aragonite grown from solution in a similar way (microtome-cut, polished, etched slightly, only for $180 \mathrm{~s}$, critical-point-dried). As is visible in Fig. A3, etch pits develop in aragonite grown from inorganic solution and nanoparticulate features are absent.

\subsection{The ultra- and microstructure of experimentally altered $A$. islandica shells}

Pieces of pristine Arctica islandica shells were altered at 100, 125,150 and $175^{\circ} \mathrm{C}$ for 1 to 84 days in fluids simulating meteoric and burial (Mg-rich) fluids (Table 1). As X-ray diffraction (XRD) measurements in Fig. A11 show, shell aragonite remains stable for the first 3 days of alteration, even at alteration temperatures of $175^{\circ} \mathrm{C}$. Alteration times up to 14 days at $125^{\circ} \mathrm{C}$ do not cause the mineral replacement reaction of Arctica islandica shell aragonite into calcite (Fig. A11). In our experiments calcite formation started on the fourth day of alteration.

In order to trace fluid infiltration into and their percolation through the shell we performed major and minor element chemical analyses by EPMA. The distribution patterns of sodium, chlorine and strontium are shown as characteristic examples (Figs. A4, A5, A6). Fluids enter the shell through pores and along growth lines, as demonstrated by the perfect correspondence between increased $\mathrm{Na}$ and $\mathrm{Cl}$ contents and the outlines of annual growth lines, indicated by elevated $\mathrm{Sr}$ contents (Fig. A4). These growth lines are readily detected by 

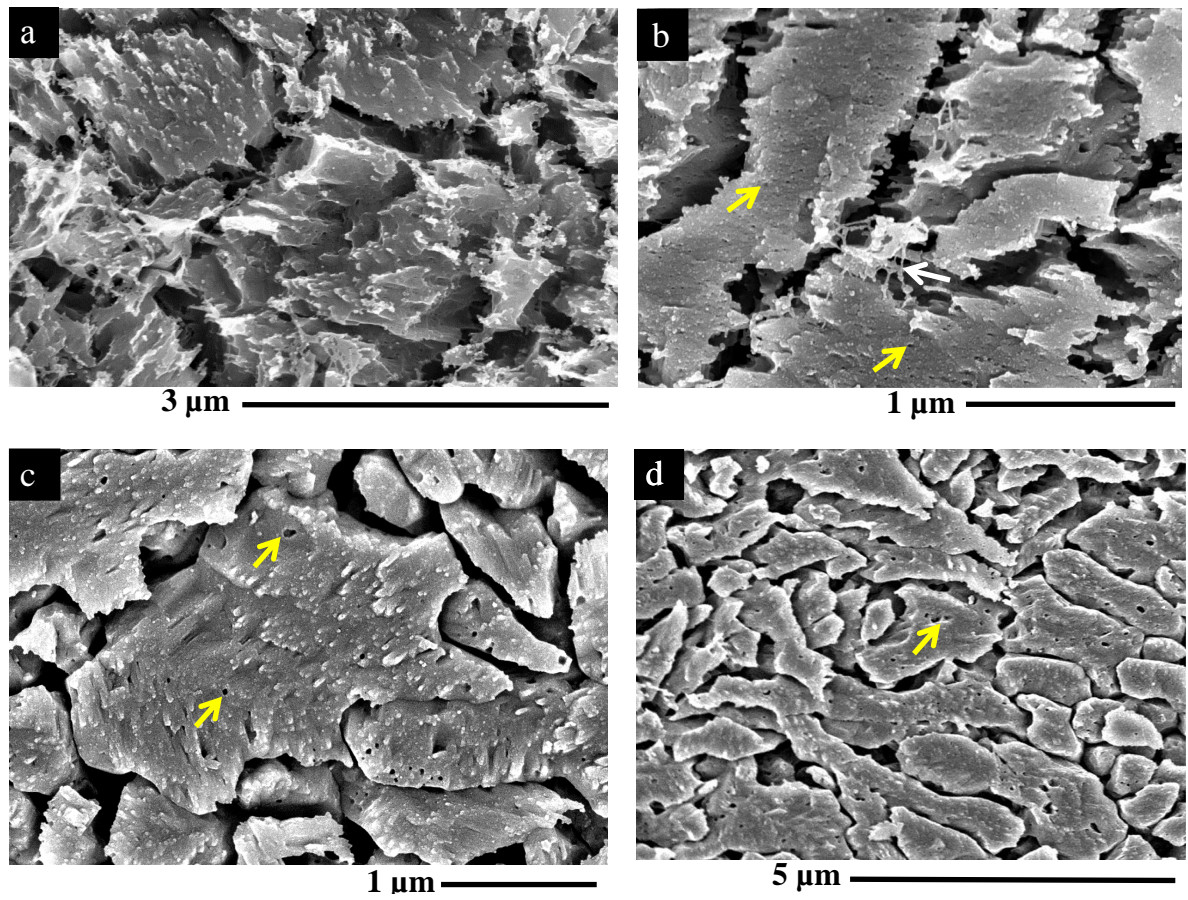

Figure 5. FE-SEM micrographs that zoom into experimentally altered Arctica islandica shell material shown in Fig. $4.10 \mathrm{mM} \mathrm{NaCl}+10 \mathrm{mM}$ $\mathrm{MgCl}_{2}$ aqueous solution (burial fluid) was used for alteration at $100^{\circ} \mathrm{C}$ for 28 days (a, b) and at $175^{\circ} \mathrm{C}$ for 7 days (c, d). Panels (a) and (c) show portions from the seawater-adjacent shell layers; (b) and (d) depict material from shell layers at the soft tissue of the animal. The biopolymers have decomposed and dissolved in the material treated at $175^{\circ} \mathrm{C}(\mathbf{c}, \mathbf{d})$. Readily observable are minute round holes within the mineral units (yellow arrows in $\mathbf{b}, \mathbf{c}, \mathbf{d}$ ) that were filled in the pristine shell, prior to alteration, by biopolymer fibrils. For further details concerning the interlinkage between mineral units and nanoparticles with organic matrices, see Figs. A7 and A8.

an increase in Sr contents in pristine (Fig. A4a) as well as in hydrothermally altered shell samples (Figs. A5, A6; see also Shirai et al., 2014). However, neither the temperature of hydrothermal alteration nor the chemistry of the alteration fluid has an influence on the amount of Sr present along growth lines. Relative to neighbouring shell increments, the $\mathrm{Sr}$ content along the growth lines is always higher (Shirai et al., 2014). Maximal concentrations (along annual growth lines) in pristine and altered shells vary between 0.4 and $0.6 \mathrm{wt} \%$ Sr (Figs. A4, A5, A6).

FE-SEM images of Figs. 4 and 5 highlight the grain structure and remnants of the organic matrix in hydrothermally altered $A$. islandica shells. In the case of the samples shown in Figs. 4 and 5, burial water was used as alteration solution; the hydrothermal treatment conditions were $100^{\circ} \mathrm{C}$ for 28 days (Figs. $4 \mathrm{a}, \mathrm{b}, 5 \mathrm{a}, \mathrm{b})$ and $175^{\circ} \mathrm{C}$ for 7 days (Figs. $4 \mathrm{c}$, d, 5c, d). SEM images on the left-hand side of Figs. 4 and 5 are taken from the outer shell section, while SEM images on the right-hand side of Figs. 4 and 5 are taken from the dense layer of the inner shell layer. Alteration at $100^{\circ} \mathrm{C}$ for 28 days did not change the internal ultrastructure of the shell significantly. The shape and size of the mineral units are retained and they are still interconnected with a few organic fibres (Figs. 4a, b, 5b). However, at $175^{\circ} \mathrm{C}$ for 7 days, the formerly present network of biopolymer fibres and membranes has vanished completely (Figs. 4c, d, 5c, d). At higher magnification a multitude of tiny holes (indicated with yellow arrows in Figs. 5c, d and enlarged in Figs. A7a and A8b) become readily visible. In the unaltered shell, these holes were filled with the network of biopolymer fibrils interconnecting the mineral units (e.g. Fig. 3b). The tiny holes in the mineral units start to become visible even in the samples altered at $100^{\circ} \mathrm{C}$ (yellow arrows in Fig. 5b). Although at $175^{\circ} \mathrm{C}$ shell aragonite has transformed to large calcite crystals (see following the description of results), etching still outlines a grain fabric on the size scale of the former bioaragonite crystal units (Figs. 4c, d). The newly formed fabric resembles that of a fine-grained inorganic ceramic material.

Aragonite crystal orientation patterns of modern $A$. islandica shells and those altered at $100{ }^{\circ} \mathrm{C}$ are presented in Figs. 6, A9, and A10 with EBSD greyscale band contrast images (upper images of Figs. 6a, b, c, A9), EBSD colour-coded orientation maps (lower images of Figs. 6a, b, c), and corresponding pole figures. Figure 6e gives grain area information deduced from the EBSD measurements that are shown in Figs. 6a to c. Alteration occurred at $100^{\circ} \mathrm{C}$, over a period of 28 days, and took place in meteoric (Fig. 6b) and burial fluid (Figs. 6c, A9), respectively. The microstructure and texture of pristine A. islandica shell material is shown in Fig. 6a. The crystallographic co-orientation in pristine and altered $A$. 

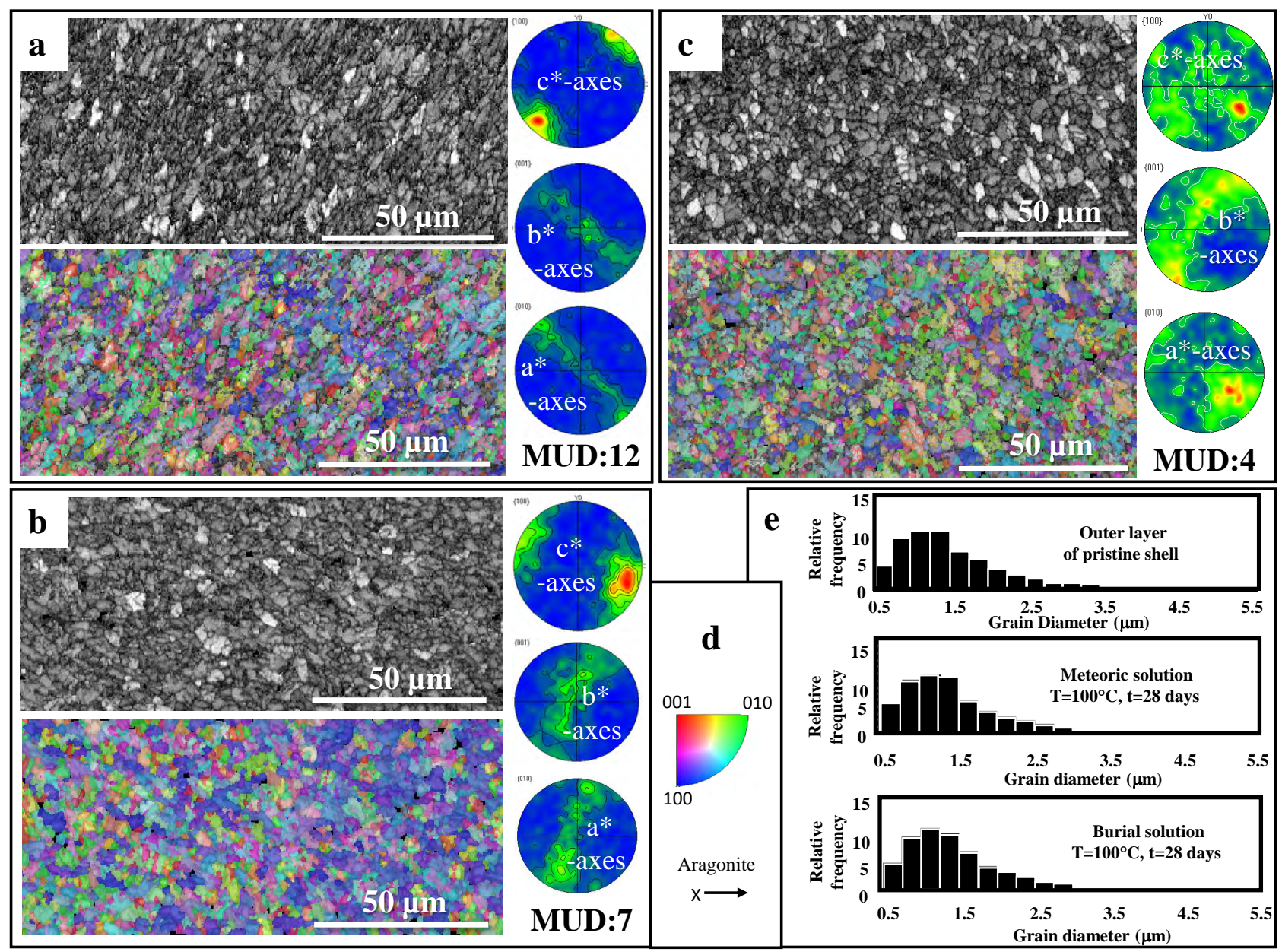

Figure 6. EBSD band contrast images (greyscale) and orientation maps (coloured; colour code given in d) with corresponding pole figures of pristine (a) and experimentally altered (b, c) Arctica islandica shell material. In the pole figures, colour is coded for pole density, with the maximum in red corresponding to the given MUD value for each set of pole figures, respectively. All EBSD measurements were taken at the outer shell layer. Hydrothermal alteration was applied for 28 days at $100^{\circ} \mathrm{C}$. The solutions used were artificial meteoric fluid in (b) and artificial burial fluid in (c). As the pole figures show, in comparison to the microstructure of pristine Arctica islandica (a), the crystal orientation pattern in the skeleton is not affected by treatment with the solutions. (e) Grain diameter statistics for pristine and experimentally altered Arctica islandica shell material obtained from the EBSD measurements are shown in (a)-(c). There is no significant difference in grain size between pristine and hydrothermally altered Arctica islandica shells.

islandica shells is axial with the $c$ axes (setting $a=4.96 \AA$, $b=7.97 \AA, c=5.74 \AA$, space group $P$ mcn) pointing approximately perpendicular to the growth lines. Co-orientation of the aragonite crystallites in the outer shell portion, even in the modern $A$. islandica, is very low with MUD values of 12 (Fig. 6a) and 32 (Fig. A10a). Hydrothermal treatment of A. islandica at $100^{\circ} \mathrm{C}$ does not produce a significant change in aragonite co-orientation pattern, texture, grain fabrics, and grain size distributions. The pristine and the hydrothermally treated shell materials appear to be quite similar. The small changes in MUD values may be attributed to the fact that it was impossible to locate the EBSD scan fields on the different samples in exactly corresponding spots with respect to the outer shell margin and to the patterns of annual growth lines. Figures 7 and A9b, c show microstructure and texture characteristics deeper within the shell (Figs. 7a, A9, A10) and at the innermost margins next to the inner shell layer (Figs. 7c, d; alteration in meteoric fluid: Figs. 7a to d; alteration in burial fluid: Figs. 7e, f). In the EBSD band contrast map of Fig. 7a we clearly see the change in microstructure from the outer shell layer with the larger aragonite crystals (yellow star in Fig. 7a) to the inward shell portion where aragonite crystals become small to minute (white star in Figs. 7a, A9b, c). As the pole figures and MUD values demonstrate, the axial $c$ and $a$ axes' co-orientation increases gradually towards the inner shell layer where MUD values of almost 100 are reached (Figs. 7d, f, A9, A10). 


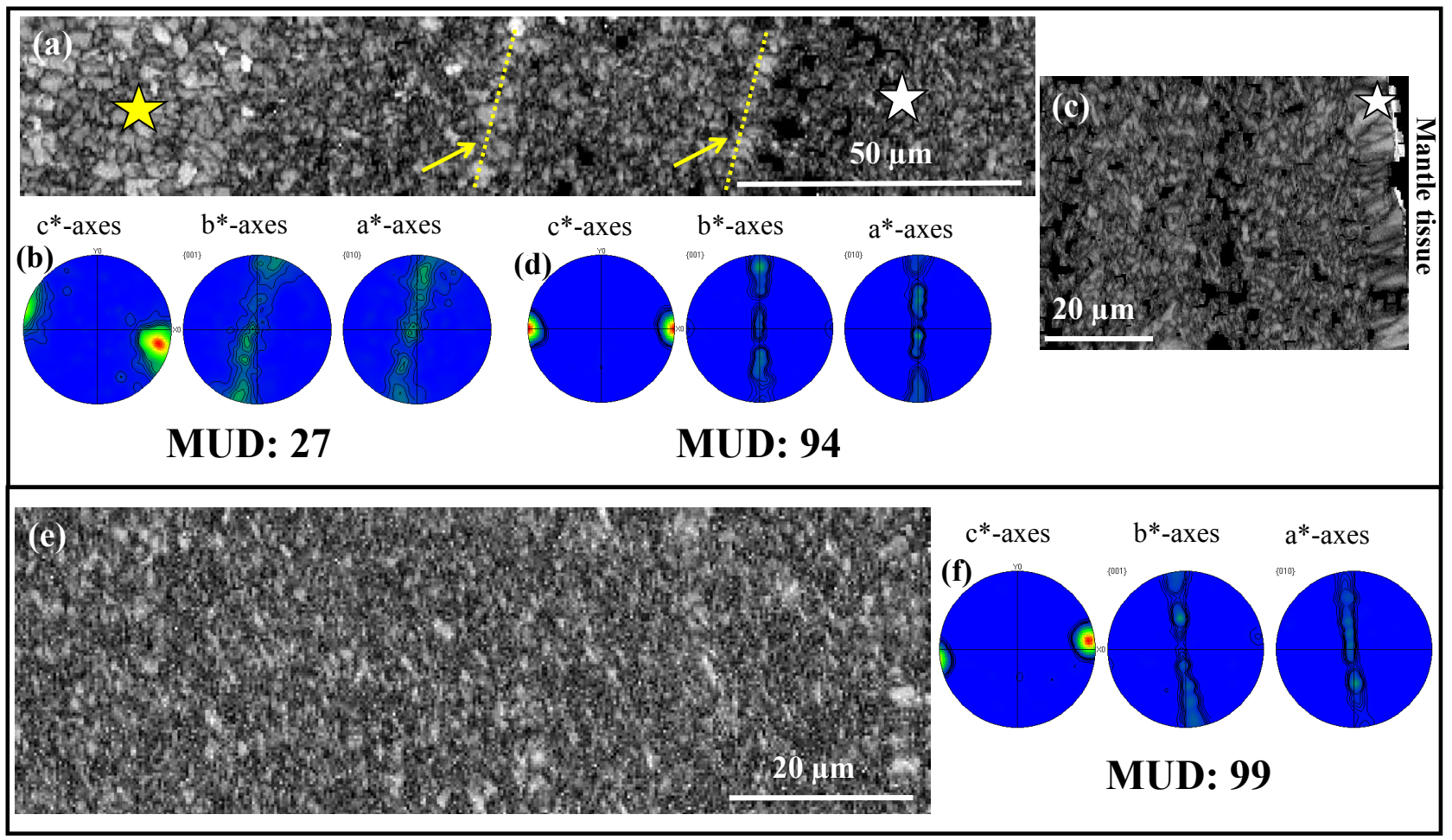

Figure 7. EBSD band contrast images (greyscale) and corresponding pole figures of hydrothermally altered (100 ${ }^{\circ} \mathrm{C}$ for 28 days) Arctica islandica shell material with artificial meteoric fluid $(\mathbf{a}, \mathbf{b}, \mathbf{c}, \mathbf{d})$ and artificial burial fluid $(\mathbf{e}, \mathbf{f})$. In (a) the change in shell microstructure is visible from the outer shell layer that contains large aragonite crystals (yellow star in a) and many pores, in contrast to the inner shell layer, which consist of densely packed small aragonite crystallites (white star in a). In (c) and (e) band contrast maps and pole figures are shown that were taken at the inner shell layer. As the pole figures and the high MUD values in (d) and (f) highlight, this part of the shell remains almost unaltered and the pristine Arctica islandica microstructure is kept. In (a) the two yellow arrows and the two dashed lines indicate the location of former growth lines where, in pristine shells, an increased amount of organic material is present. As the latter is destroyed during hydrothermal alteration, space becomes available for infiltration of fluids. For further details, see Fig. A9.

Using XRD we obtained an overview of the kinetics of the $A$. islandica biogenic aragonite to calcite transition under hydrothermal conditions up to $175^{\circ} \mathrm{C}$ in artificial burial solution (Figs. 8a, b, A11). A representative Rietveld plot of the analysis of the XRD data obtained for the 6-day alteration is given in Fig. A12. As Fig. A9 demonstrates, experiments below $175^{\circ} \mathrm{C}$ show no signs of a replacement reaction of bioaragonite to calcite in the XRD bulk measurements. At $175^{\circ} \mathrm{C}$ in burial solution, calcite formation starts after a passive period of about 4 days (Figs. 8a, b, A11) and then proceeds rapidly. After 7 days only a few patches of aragonite in the dense shell layer are not yet completely transformed to calcite (as seen in the EBSD investigations, unaltered shell portions are indicated with white rectangles in Fig. 1a). After 8 days the transition to calcite is complete.

EBSD data clearly show that after a hydrothermal treatment at $175^{\circ} \mathrm{C}$, with either meteoric or burial fluid, shell aragonite is transformed to calcite (Figs. 9, 10 and 11). In the outer shell layer the replacement reaction to calcite is complete with the development of large crystal grains, some reaching sizes of hundreds of micrometres (see EBSD maps in Figs. 9 and 10). In contrast, dense shell regions devoid of pores still retain patches of the original aragonitic microstructure and texture (coloured EBSD maps in Figs. 11a, b). The MUD values for the newly formed calcite material are high (Figs. 9, 10), but this is related to the fact that, within the range of the EBSD scan, just a small number of large, newly formed, individual crystals are encountered. Figure 11 shows shell regions where patches of aragonite have survived which contain first-formed calcite. Calcite nucleation sites are the locations where the experimental fluid has access to the shell: at its outer and inner surfaces (yellow stars in Fig. 11b) and at growth lines (yellow arrows in Fig. 11a). Figure 11a demonstrates how calcite crystals form strings along linear features, which correspond to growth lines in the pristine shell material. 

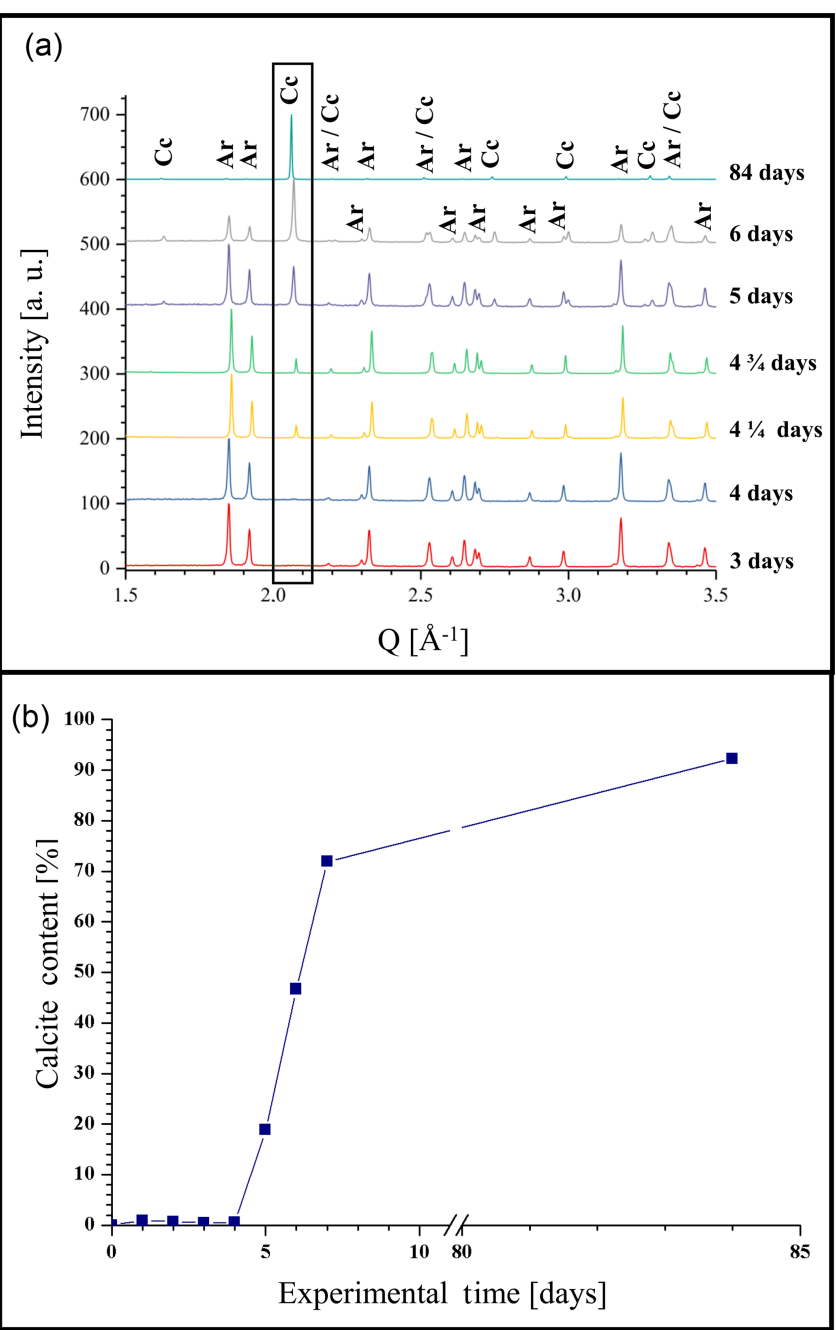

Figure 8. (a) Selected X-ray diffractograms for 3 to 84 days of alteration of Arctica islandica shell material. Alteration took place in artificial burial solution at $175^{\circ} \mathrm{C}$. (b) Newly formed calcite content relative to alteration time (days) calculated from Rietveld analyses of the XRD measurements.

\section{Discussion}

\subsection{Driving force in comparison to nucleation barrier}

In sedimentary environments the fate of metastable biogenic aragonite or high-Mg calcite can follow two scenarios: (1) the metastable biogenic matter can be completely dissolved and removed by fluid transport to form moulds that are later filled by cement or other neogenic minerals or (2) the metastable minerals may be replaced by stable low$\mathrm{Mg}$ calcite in situ through a process which involves dissolution of the metastable phase into a nano- to microscale local fluid volume (e.g. a thin fluid film) from which the stable low-Mg calcite precipitates without long-range transport (Brand and Veizer, 1980, 1981; Brand, 1991, 1994; Bathurst, 1994; Maliva, 1995, 1998; Maliva et al., 2000; Titschak et al., 2009, Brand et al., 2010). The latter process may preserve original morphological boundaries and microstructures such as prisms, tablets and fibres in bivalve shells. The replacement reaction from aragonite to stable low-Mg calcite is driven by the higher solubility (free energy) of the metastable phase compared to the stable phase. Thus, as the replacement reaction proceeds, the reactive, percolating experimental or diagenetic pore fluid becomes undersaturated with respect to aragonite owing to its relative supersaturation with respect to calcite, the less soluble mineral phase in the system. In a fluid which draws its calcium and carbonate ions from the dissolution of aragonite, the maximal supersaturation $\Omega_{\max }$ with respect to calcite can be described as

$\Omega_{\max }=\frac{K_{\mathrm{sp}}(\text { aragonite })}{K_{\mathrm{sp}} \text { (calcite) }}$,

where $K_{\mathrm{sp}}$ stands for the ion activity products of the respective phase in the relevant pore fluid. The free-energy difference or thermodynamic driving force is given by $\Delta \mathrm{G}_{\max }=$ $-R T \ln \Omega_{\max }$. To obtain an estimate we used the data of Plummer and Busenberg (1982) and calculated the solubility products for calcite and aragonite for 25,100 , and $175^{\circ} \mathrm{C}$ (Fig. 12). The maximal supersaturations $\Omega_{\max }$ thus obtained are $1.39\left(25^{\circ} \mathrm{C}\right), 1.26\left(100^{\circ} \mathrm{C}\right)$, and $1.18\left(175^{\circ} \mathrm{C}\right)$. The replacement reaction first requires a nucleation step: the formation of the first calcite crystallites larger than the critical size $r^{*}$ (Morse et al., 2007). Empirical nucleation theory relates the activation energy $\Delta G_{\mathrm{A}}\left(r^{*}\right)$ necessary to form a nucleus of critical size to the specific surface energy $\sigma$ needed to form the interface between the nucleating phase and the matrix phase as

$\Delta G_{\mathrm{A}}\left(r^{*}\right) \propto \frac{\sigma^{3}}{(-R T \ln \Omega)^{2}}$.

Only supercritical nuclei or pre-existing seed crystals of size $r>r^{*}$ of calcite can lower their free energy as their volume of free energy gained by growth exceeds the adverse energy contributions of increasing interface area. To obtain a significant number of supercritical nuclei a critical supersaturation needs to be reached (Morse et al., 2007; Gebauer et al., 2008; Nindiyasari et al., 2014; Sun et al., 2015). Reported values for critical supersaturation levels $\Omega_{\text {crit }}$ required for calcite nucleation in various conditions range from the order of 3.7 (Lebron and Suarez, 1996; Zeppenfeld, 2003) to the order of 30 (Morse et al., 2007; Gebauer et al., 2008) or even several hundreds in, for example, hydrogel matrices (Nindiyasari et al., 2014). The density functional theory study of Sun et al. (2015) arrives at $\Omega_{\text {crit }}=5$ for systems free of inhibitors such as $\mathrm{Mg}$, and $\Omega_{\text {crit }}=35$ for modern seawater. Accordingly, the supersaturation produced by the dissolution of aragonite is very small compared to supersaturation levels typically required for the nucleation of calcite. Thus, we can expect that nucleation is a critical kinetic step in the replacement reaction of aragonite by calcite. 

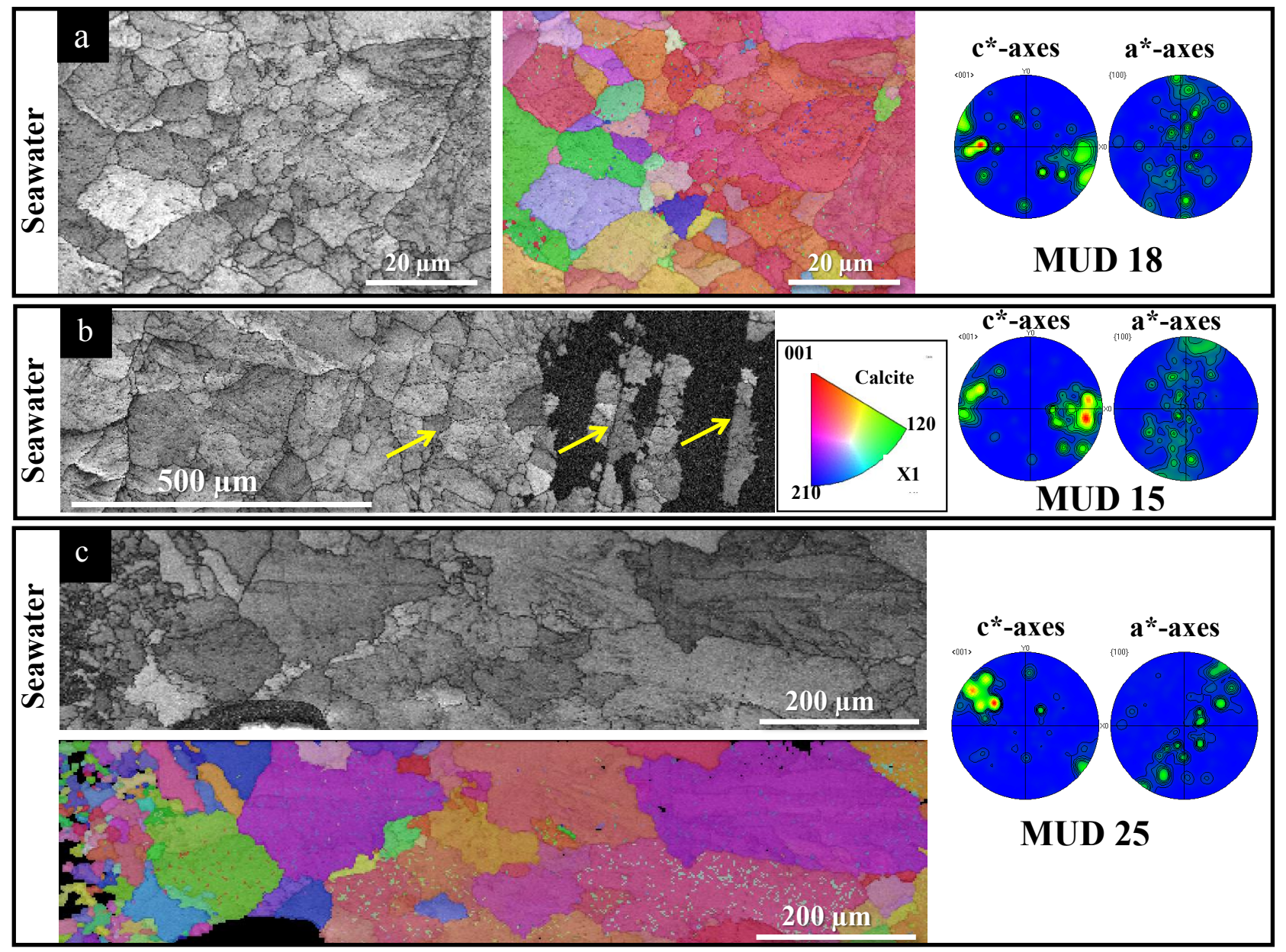

Figure 9. EBSD band contrast maps, colour-coded orientation maps, and corresponding pole figures highlight the microstructure and texture of Arctica islandica shells altered at $175^{\circ} \mathrm{C}$ in artificial meteoric solution. EBSD measurements shown in (a) and (b) were taken on shells that were subject to hydrothermal alteration for 7 days. Measurements shown in image $\mathrm{C}$ refer to shells where alteration lasted for 84 days. At $175^{\circ} \mathrm{C}$, for both alteration times, aragonite was almost completely replaced by calcite and the shell microstructure is characterised by large and randomly oriented calcite crystals. The initial growth of calcite is visible at the location of former growth lines (yellow arrows in b). For further microstructural details of the pristine shell material, see Fig. A9.

\subsection{Aragonite metastability at $100^{\circ} \mathrm{C}$ up to $160^{\circ} \mathrm{C}$}

In our laboratory-based hydrothermal alteration experiments at $100{ }^{\circ} \mathrm{C}$ in both meteoric and burial fluids, the aragonite mineral and the characteristic biological microstructure survive the hydrothermal treatment up to at least 28 days. In experiments at $125^{\circ} \mathrm{C}$ and $150{ }^{\circ} \mathrm{C}$ we did not see any calcite formation from the bioaragonite either. This is consistent with the findings of Ritter et al. (2017), who analysed the light-stable isotope signatures $\left(\delta^{13} \mathrm{C}, \delta^{18} \mathrm{O}\right)$ of hydrothermally treated samples. In the $100^{\circ} \mathrm{C}$ alteration experiments using isotope-doped experimental fluids, Ritter et al. (2017) found that the carbon and oxygen isotope ratios of the treated shells are within the same range as those measured in the pristine samples. Furthermore, no obvious patterns emerge from the comparison of sub-samples exposed to seawater, meteoric, and burial fluids. Most of the extensive literature on aragonite precipitation from aqueous solutions and aragonite-calcite replacement reactions in aqueous environments, as reviewed in the introduction, makes it clear that both temperatures around the boiling point of water and the presence of $\mathrm{Mg}^{2+}$ inhibit calcite nucleation. Thus, the inhibition of calcite nucleation favours the growth of aragonite if the solution is supersaturated with respect to the calcium carbonate phases. If supersaturation is exceedingly high and rapidly generated, vaterite or even amorphous calcium carbonate will precipitate and reduce the supersaturation below the levels required for aragonite or calcite nucleation (Navrotsky, 2004; Gebauer et al., 2008, 2012; Radha et al., 2010). However, it is unlikely that these levels of supersaturation are reached in our case, as aragonite is already present. We thus conclude that the absence of an aragonite to calcite 


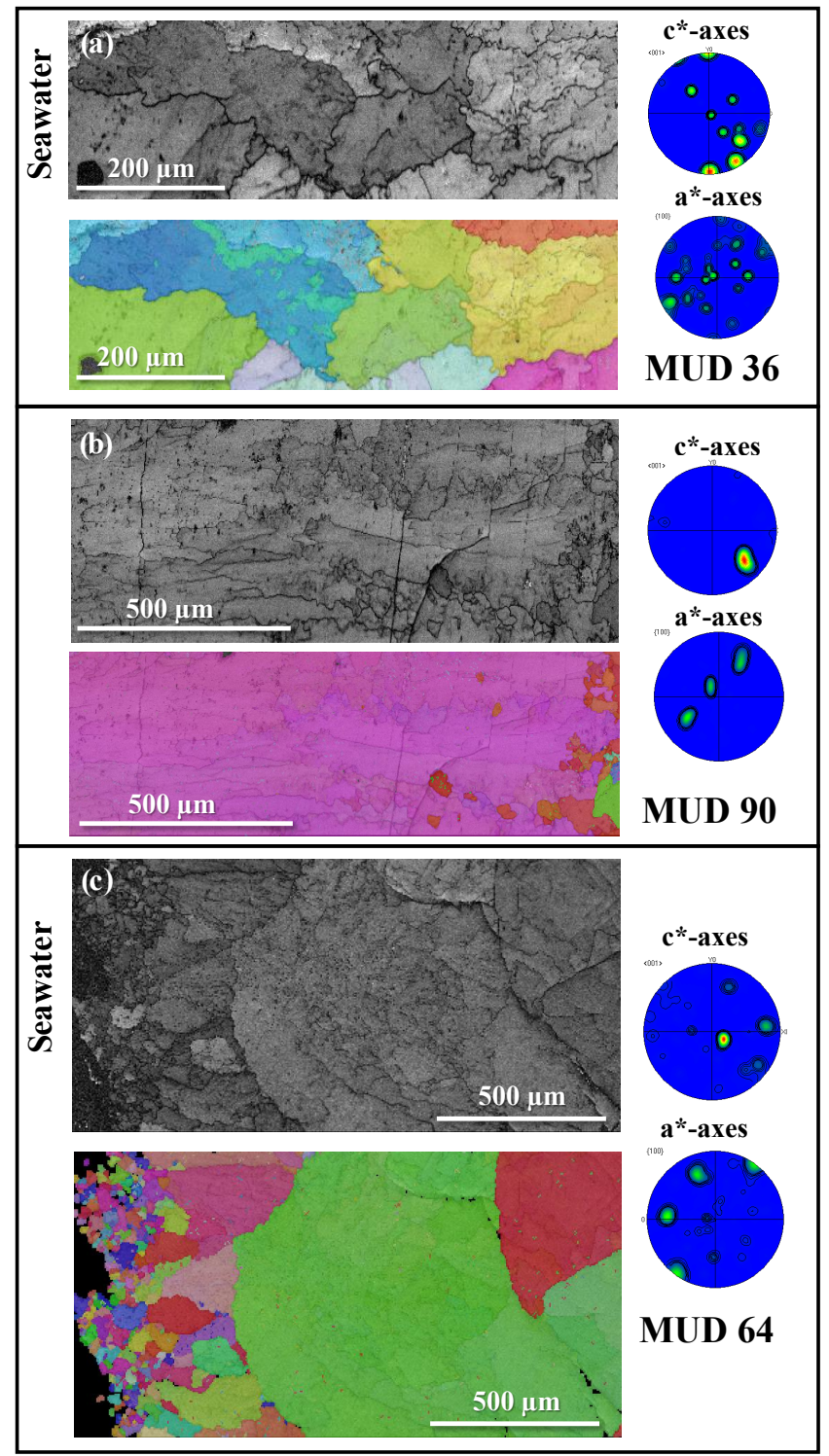

Figure 10. EBSD band contrast maps and colour-coded orientation maps with corresponding pole figures for hydrothermally altered Arctica islandica shells at $175^{\circ} \mathrm{C}$ in water simulating burial diagenesis. EBSD measurements shown in (a) and (b) were taken on shells that were subject to hydrothermal alteration for 7 days, while the measurement shown in (c) was performed on shells where alteration lasted for 84 days. At $175^{\circ} \mathrm{C}$, for both alteration times, most of the aragonite has transformed to calcite.

replacement reaction in our $100-150^{\circ} \mathrm{C}$ treatments is related to inhibition of calcite nucleation (Sun et al., 2015), a mechanism that has rarely been rigorously explored.

\subsection{Dormant period followed by rapid reaction at $175^{\circ} \mathrm{C}$}

At $175^{\circ} \mathrm{C}$ the replacement reaction of biological aragonite to coarse-grained calcite occurs rapidly; it starts after a dor- mant period of about 4 days and proceeds rapidly almost to completion after 3 more days (Figs. 8, A11). However, even after 84 days about $5 \%$ of residual aragonite is still present. Calcite nucleation occurs (and replacement reaction proceeds) where the experimental fluid is in contact with the bio-aragonite: at the surfaces of the shell, in pores and along growth lines (Figs. 9b, 11, A4-A6).

\subsection{Nucleation and the time lag of the aragonite to calcite replacement reaction at $175^{\circ} \mathrm{C}$}

A certain time lag in the hydrothermal treatment experiments is expected for the initial dissolution of shell aragonite to build up a sufficiently high ion activity product in the solution to precipitate any calcite. However, the several-day dormant period followed by the rapid growth of calcite indicates that the nucleation of calcite is inhibited, at least initially. We discussed in the previous section that the thermodynamic potential (supersaturation) for the formation of calcite from a fluid which is able to dissolve aragonite is smaller than the critical supersaturation required to obtain a discernible nucleation rate for calcite in normal laboratory experiments. The presence of magnesium in the solution further inhibits calcite nucleation, as do high temperatures between 70 and $160^{\circ} \mathrm{C}(\mathrm{Ki}-$ tano et al., 1962; Taft, 1967; Kitano et al., 1972; Katz, 1973; Berner, 1975; Morse et al., 1997; Choudens-Sánchez, 2009; Radha et al., 2010; Perdikouri et al., 2011, 2013; Balthasar and Cusack, 2015; Sun et al., 2015), which is supported by the lack of calcite formation in our experiments between 100 and $150{ }^{\circ} \mathrm{C}$ (Table 1, Fig. A11). A possible scenario explaining the dormant period could be simply that the nucleation rate of calcite is extremely small due to the limited supersaturation but is non-zero. Once a few nuclei formed after a few days, the actual growth process proceeds rapidly from these few nuclei. Another scenario may be the initial, rapid formation of a passivation layer on the surface of the aragonite or on the surface of any calcite nuclei; the dormant period is then the time that is needed to dissolve this passivation layer, at least in some places, where subsequently calcite nuclei of critical size can form. In order to explain this second scenario we can only speculate that, after initial dissolution of the biogenic aragonite with excess free energy due to its hybrid nanoscale composite structure, an inorganic aragonite precipitates first on the surface of the biogenic aragonite.

\subsection{Grain size and chemistry of the newly formed calcite}

Compared to the nano- to microscale grain fabric of the original aragonite material, the newly formed calcite crystals are remarkably large. In meteoric solutions the grain size of the newly formed calcite reaches $200 \mu \mathrm{m}$ (e.g. Fig. 9c), while in the Mg-bearing burial solution newly formed calcite crystals reach sizes in the $1 \mathrm{~mm}$ range, in both the 7 - and 84-day treatments (e.g. Figs. 10b, c). The large calcite grains obtained 


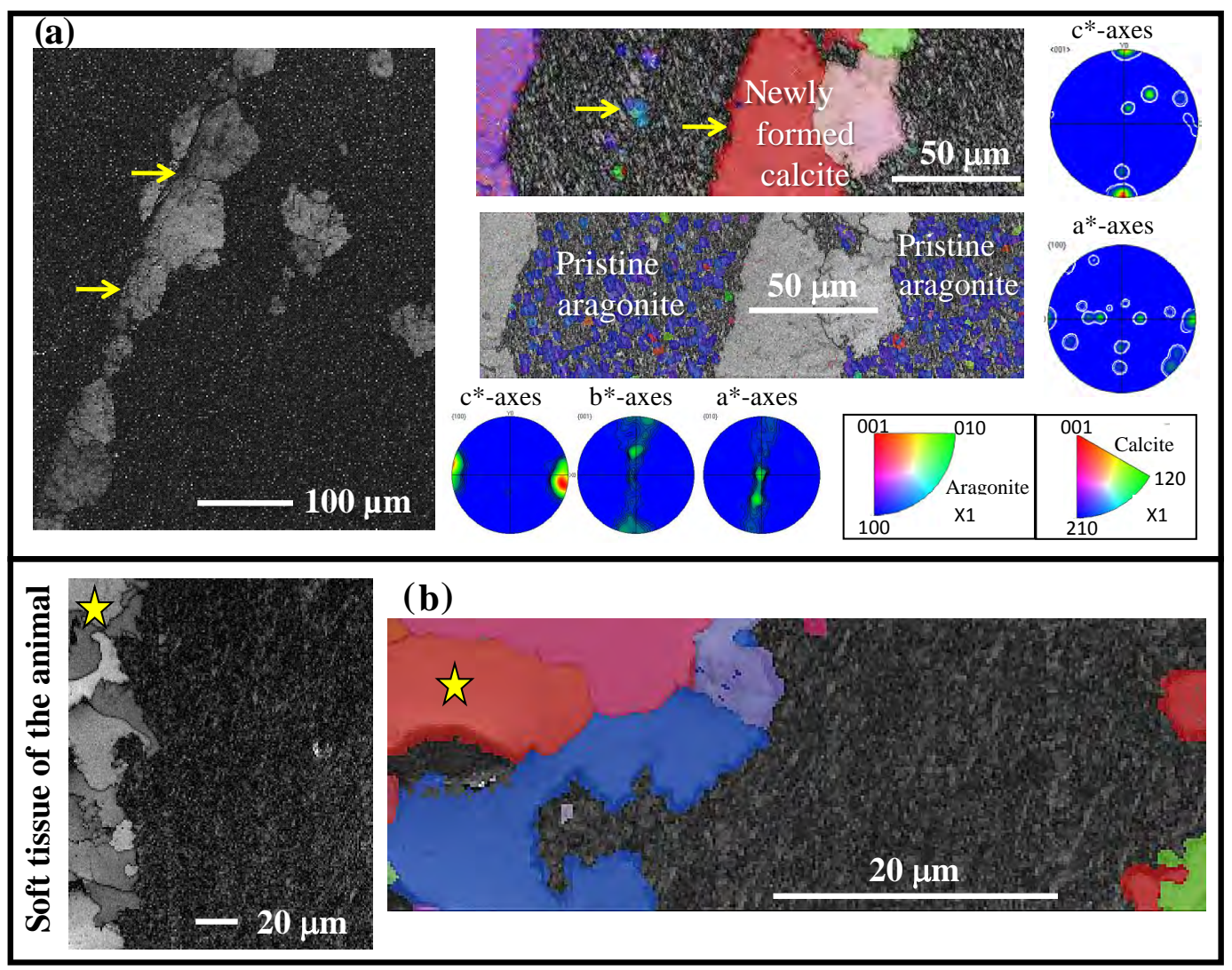

Figure 11. EBSD band contrast (in grey), crystal orientation (colour-coded for orientation) maps, and corresponding pole figures of altered Arctica islandica shells at $175^{\circ} \mathrm{C}$ in artificial meteoric (a) and burial (b) solution. Clearly visible is the initial formation of calcite at the location of former growth lines (yellow arrows in a) and the growth of large calcite crystals (yellow stars in b) that formed at the shell portion that is in direct contact with the alteration solution. Note that some pristine aragonite in the dense shell portion is still present.

can very likely be the result of the formation of very few calcite nuclei.

Other explanations for the formation of large calcite grains from the original nano- to microscale grain fabric may be Ostwald-ripening or strain-driven grain growth of the newly formed calcite. The latter could be expected due to the $8.44 \%$ volume increase when the denser aragonite transforms to calcite. To elucidate this possibility we determined the local misorientation within the calcite crystals from the EBSD data sets. Maps showing small lattice orientation changes between neighbouring measurement points highlight high dislocation densities and subgrain boundaries, which may have been introduced during the replacement reaction by stresses.

Figure 13 depicts the distribution pattern of local misorientation within five selected EBSD maps (Figs. 13b, e, h, k, n). Legends accompany all local misorientation maps (Figs. 13c, $\mathrm{f}, \mathrm{i}, \mathrm{l}, \mathrm{o})$. Blue colours indicate the absence of measurable internal misorientation, while light-green to yellow colours highlight areas where local misorientation is larger than experimental resolution. Grains in Fig. 13 are defined by a critical misorientation selected as $5^{\circ}$ (i.e. tilts smaller than $5^{\circ}$ are counted as subgrain boundaries in the mosaic structure of the crystals).

For the better visualisation of individual grains, we outlined these with white lines. In Fig. 13g, j, and $\mathrm{m}$ the mosaic structure in the grains is visible in inverse pole figure colouring reflecting lattice orientation. In all five investigated data sets the grain-internal local misorientation reaches up to $2^{\circ}$; thus, neither alteration time nor the chemical composition of the alteration solution used shows any discernible influence on the degree of strain accumulation within the calcite grains. Figure 14 compares the subgrain (mosaic) structure of two large calcite grains obtained in the same experimental fluid at $175^{\circ} \mathrm{C}$, where one grain is from the 7-day treatment, and the other from the 84-day treatment. The grains are marked by stars in Fig. 13k and n, respectively. In these maps of Fig. 14 the colour is coded for misorientation relative to a common reference point, rather than for local misorientation. Corresponding legends are given below the grains. The internal misorientation (mosaic spread) for the grain obtained in the 84-day treatment is much higher than that in the grain obtained in the 7-day treatment. We find that the local misorientations are mainly curvilinear structures in the cross sec- 


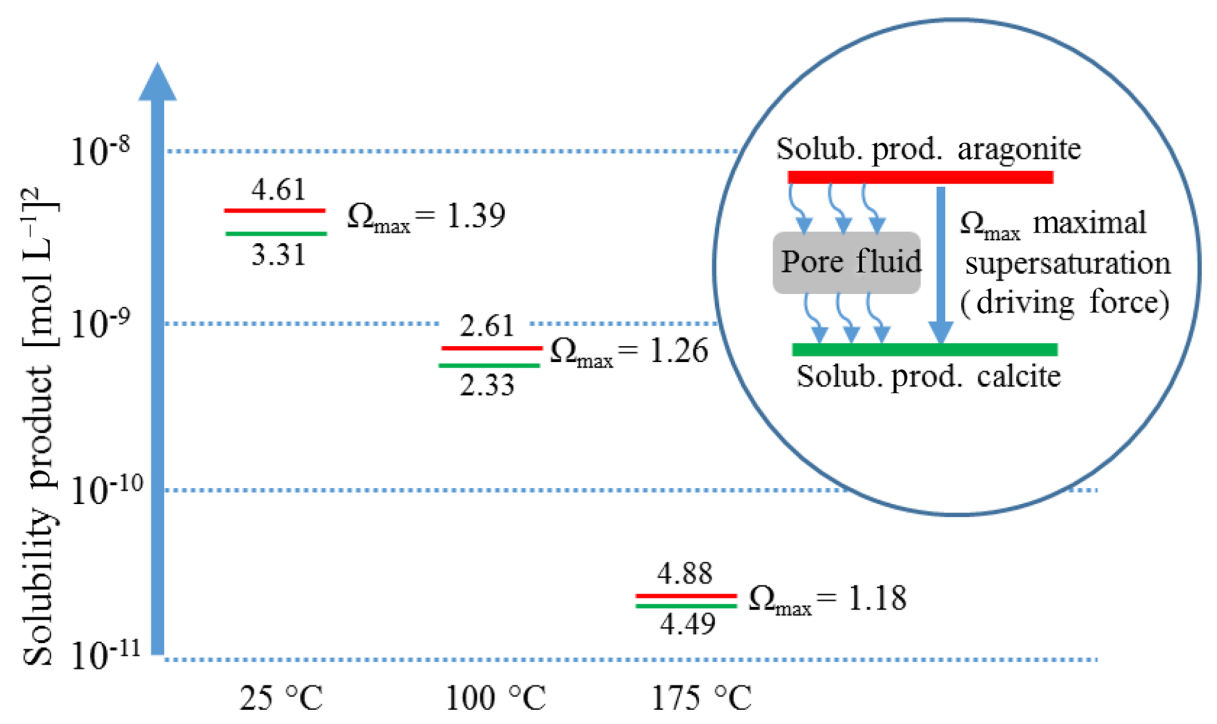

Figure 12. Solubility products of aragonite and calcite calculated from the data of Plummer and Busenberg (1982). The labels at the ordinate give the powers of 10 , and the numbers in the plot give the mantissa of the SP. $\Omega_{\max }$ is the difference between the value for aragonite (red) and calcite (green), and it is the upper bound of the supersaturation available to drive calcite precipitation from aragonite dissolution (thermodynamic driving force $\Delta_{\max }=R T \ln \Omega_{\max }$ ). To drive dissolution of aragonite and precipitation of calcite at non-zero rates, the pore fluid needs to be undersaturated with respect to aragonite and supersaturated with respect to calcite.

tion (white arrows in Fig. 14a, c) and correspond to subgrain boundaries within the newly formed calcite crystals. These boundaries do not appear to heal or to disappear with an increased alteration time, an indication again of the negligible effect of alteration duration on the fabric and internal structure of calcite grains crystallised from Arctica islandica shell bioaragonite.

To further investigate potential grain growth patterns, we took a statistical approach in the analysis of the EBSD measurements shown in Figs. 9 and 10 (alterations experiments carried out for 7 and 84 days at $175^{\circ} \mathrm{C}$ in meteoric and burial solution, respectively). Figure 14a and b show the statistics of grain area (again, we define a grain by a critical misorientation of $5^{\circ}$ ) versus mean misorientation within a grain. Based on these statistics, we do not see major evidence for a specific calcite grain growth phenomenon with an increase in alteration time between 7 and 84 days, with the exception of three extremely large grains in the 84-day treatment in burial solution. However, we find that experiments conducted with the Mg-containing burial solution yield larger calcite crystals (black arrows in Fig. 15b) in comparison to the size of the grains obtained from experiments carried out with meteoric water (Fig. 15a). Grains obtained from alteration experiments with meteoric fluid show a significantly higher degree of mean misorientation (up to $10^{\circ}$, black arrows in Fig. 15a), compared to the grains that grew in burial solution. Large mean misorientations of $>4^{\circ}$ occur notably in the grains grown in the 7-day treatment in meteoric solution, while the corresponding 84-day treatment does not show a significant increase in grain area compared to the 7day treatment.

In summary, the observations do not support scenarios of Ostwald-ripening or strain-driven anomalous grain growth as the reasons of the large calcite grains. We attribute the large calcite grains to the nucleation rate: the crystals growing from each nucleus consumed the aragonite educt (the precursor, original aragonite) until they abutted each other. Thus, larger crystals in the experiment with burial solution result from a smaller number of calcite nuclei, which may be attributed to the presence of aqueous $\mathrm{Mg}$ in the experimental fluid. Note here that both the reduction in Mg concentration in the reactive fluid, compared to that in the initial burial fluid (see Table 1), and speciation calculations suggest that the formation of Mg-bearing carbonate minerals (magnesite and/or dolomite) is likely possible to occur at the experimental conditions. Indeed, we observe small patches of newly formed Mg-rich carbonates (Fig. A13). The formation of such minerals occurs at lower rates compared to pure Cabearing carbonates owing to the slow dehydration of aqueous $\mathrm{Mg}$ that is required prior to its incorporation in the crystal (e.g. Mavromatis et al., 2013) even at temperature as high as $20{ }^{\circ} \mathrm{C}$ (Saldi et al., 2009, 2012).

The newly formed calcite contains only small amounts of magnesium (Table A1) in the order of $0.1 \mathrm{wt} \%$ (or 0.006 in the formula unit), while the strontium content of the original aragonite in the order of $0.4 \mathrm{wt} \%$ is retained in the calcite (0.005 in the formula unit). The local formation of Mg-rich carbonates occurs at some places at the rim of the sample, where it is in direct contact with the bulk of the experimen- 


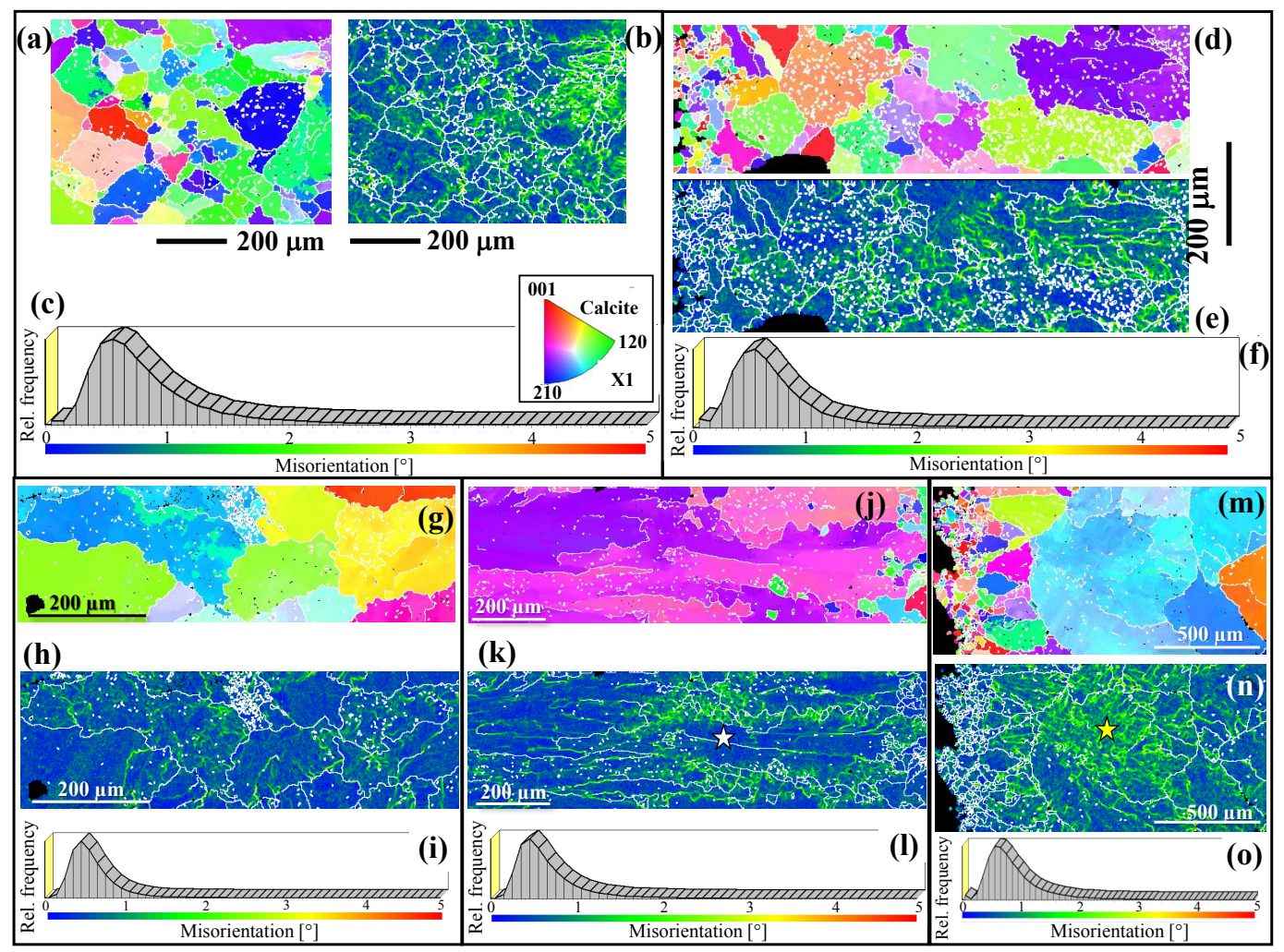

Figure 13. Calcite grain structure $(\mathbf{a}, \mathbf{d}, \mathbf{g}, \mathbf{j}, \mathbf{m}$; inverse pole figures colours as indicated in the insert in $\mathbf{c}$ ) and maps of grain-internal local misorientation distribution (b, e, ,h, $\mathbf{k}, \mathbf{n}$, scales and probability distributions given in $\mathbf{c}, \mathbf{f}, \mathbf{i}, \mathbf{l}, \mathbf{o}$ ) for experimentally altered shells of $A$. islandica carried out in simulated meteoric solution at $175^{\circ} \mathrm{C}$ for $7(\mathbf{a}-\mathbf{c})$ and 84 days $(\mathbf{d}-\mathbf{f})$, and in burial solution at $175^{\circ} \mathrm{C}$ for $7(\mathbf{g}-\mathbf{l})$ and 84 days (m-o). Grains are defined by using a critical misorientation of $5^{\circ}$. Local misorientation reaches up to $2-3^{\circ}$ (see legends in $\mathbf{c}, \mathbf{f}, \mathbf{i}, \mathbf{l}$, $\mathbf{o})$, irrespective of alteration duration and solution. The white star in (k) marks stress-free shell portions, while the yellow star in (n) indicates the location of an increased stress accumulation.

tal fluid (Fig. A13b and Table A1). In these patches, measured $\mathrm{Mg}$ contents reach up to $19.7 \mathrm{wt} \%$ (0.716 in the formula unit, encountered in scan field 3 at the outer rim of the sample). The averaged composition in scan fields 4 and 9 in Fig. A13b may indicate dolomite, but like scan field 3, which has a $\mathrm{Mg}$ content exceeding that of dolomite, we more likely have magnesite with some calcite present, as judged from the EPMA map (Fig. A13b).

\subsection{The calcite to aragonite replacement reaction kinetics}

Inorganic experiments on aragonite to calcite transition at $108^{\circ} \mathrm{C}$ in hydrothermal conditions were reported by Bischoff and Fyfe (1968) and by Bischoff (1969). These authors used fine-grained powders as educts (the precursor, original material) and observed a comparatively rapid transition to calcite that was complete within $48 \mathrm{~h}$, depending on the composition of the fluid. For example, larger $\mathrm{CO}_{2}$ partial pressure (leading to lower $\mathrm{pH}$ and thus larger solubility of the carbonates) accelerated, while the presence of $\mathrm{Mg}$ ions retarded the process. This rapid reaction kinetics as reported by Bischoff and Fyfe (1968) and by Bischoff (1969) are inconsistent with our observations. We do not see a replacement reaction of the biogenic aragonite to calcite at $100^{\circ} \mathrm{C}$ even within 28 days. Hydrothermal experiments by Metzger and Barnard (1968) and by Perdikouri and co-workers (2011, 2013), however, who used aragonite single crystals in their experiments, report reaction kinetics which correspond very well to our observations. They do not observe any evidence of the replacement reaction at $160^{\circ} \mathrm{C}$ even within 1 month but rather a partial replacement of their aragonite crystals by calcite within 4 weeks at $180^{\circ} \mathrm{C}$. We observed that the fluids used (artificial meteoric and/or burial fluids) cause only a minor difference in replacement reaction kinetics in our experiments, with the $\mathrm{MgCl}_{2}$-bearing artificial burial fluid reducing the nucleation rate of calcite, thus leading to the observed significantly larger calcite crystals in the product. As compared to the work of Perdikouri et al. $(2011,2013)$ on aragonite single crystals, shell aragonite does not crack during the replacement of the aragonite by calcite. The reason for this difference may be ascribed to the porosity of the bioaragonite, which results from the loss of its organic component. As Fig. 5c-d and the band contrast and orien- 


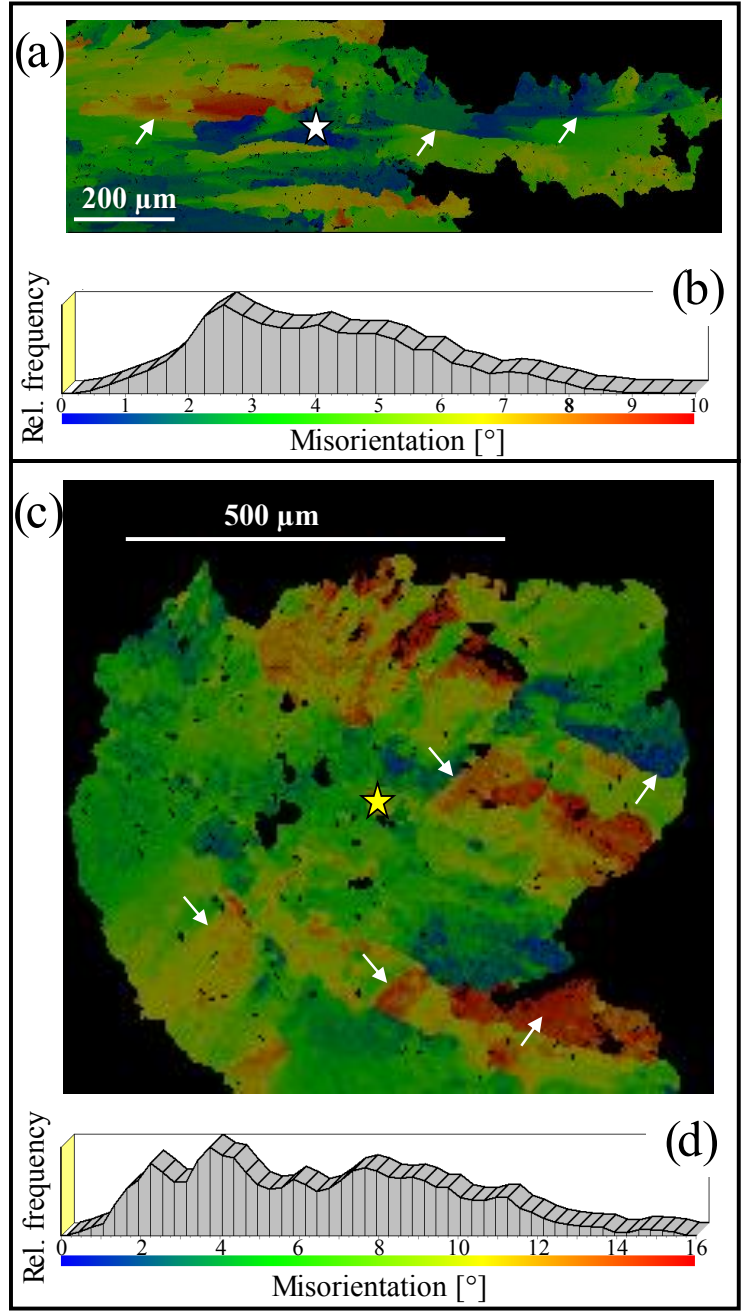

Figure 14. Colour-coded visualisation (a, c) and degree of internal misorientation $(\mathbf{b}, \mathbf{d})$ within two large, millimetre-sized grains that grew in simulated burial solution at $175^{\circ} \mathrm{C}$ for 7 (a) and 84 (c) days. The grain shown in (a) contains some stress-free portions within its centre (indicated by blue colours and the white star in a), while internal misorientation in the grain shown in (c) is highly increased and occurs everywhere within the grain (d). The yellow star in (c) points to the region where, in this grain, stress accumulation is highest.

tation maps of Fig. 6a-c illustrate, the (newly formed) calcite product reveals an internal structure that is very reminiscent of the original bioaragonite-biopolymer composite. The structure arises as the solution penetrates along former sites of organic matrix (former aragonite grain boundaries), such that the structural features obtained after alteration still outline the former aragonite grains. Thus, limited grain sizes of the bioaragonite together with the formerly biopolymerfilled spaces reduce any stresses that may be built up by the specific volume change of the $\mathrm{CaCO}_{3}$ during the replacement reaction. The replacement process preserves original morphological features. Several studies (Putnis and Putnis,

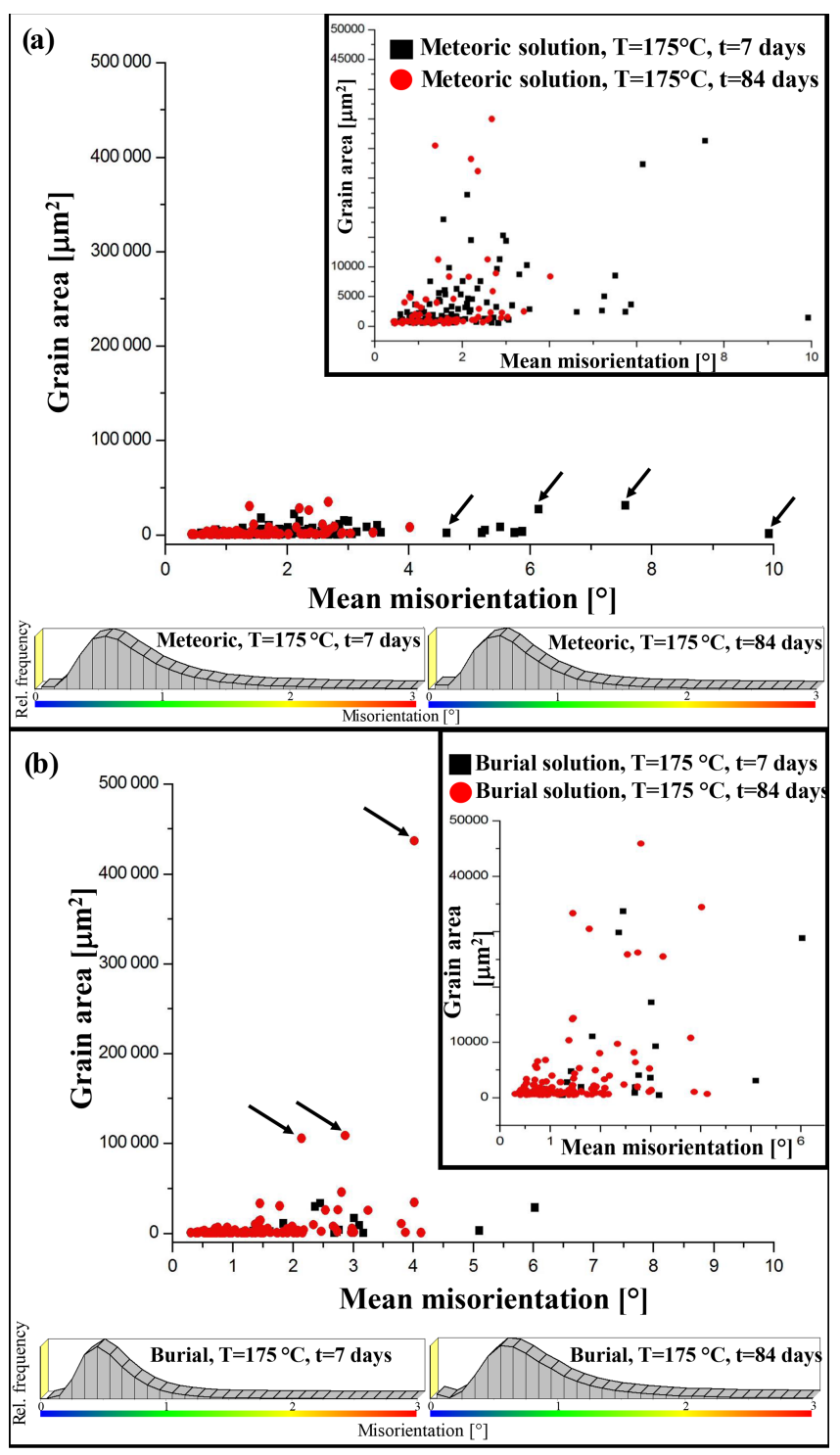

Figure 15. Grain area versus mean misorientation within individual grains obtained for newly formed calcite at alteration of Arctica islandica aragonite in artificial meteoric (a) and in burial (b) solutions at $175^{\circ} \mathrm{C}$ and for 7 and 84 days, respectively. The Mg-containing (burial) alteration fluid induces the formation of large calcite grains that show a low degree of misorientation within the grains (b), while with artificial meteoric solution, the solution that is devoid of $\mathrm{Mg}$, significantly smaller grains are obtained. However, the latter occur with a high mean misorientation within the individual, newly formed grains.

2007; Xia et al., 2009; Putnis and Austrheim, 2010; Kasioptas et al., 201; Pollok et al., 2011) experimentally investigated mineral replacement reactions creating pseudomorphs, even reproducing exquisite structures such as the cuttlebone of Sepia officinalis. These studies conclude that the essential factor in producing pseudomorphs is the dissolution of the replaced parent material as the rate-limiting step once 
the replacement reaction proceeds, while the precipitation of the product phase and the transport of solution to the interface must be comparatively fast. The preservation of morphology - even as observed on the nano- to microscale is ensured if nucleation and growth of the product immediately take place at the surface of the replaced material when the interfacial fluid film between the dissolving and the precipitating phase becomes supersaturated in the product after dissolution of the educt: an interface-coupled dissolutionreprecipitation mechanism (Putnis and Putnis, 2007). If dissolution of the educt is fast and precipitation of product is slow, more material is dissolved than precipitated, and the solutes can be transported elsewhere. Not only would this create an increased pore space which potentially collapses under pressure but the dissolved material would also eventually precipitate elsewhere with its own characteristic (inorganic) morphology rather than reproducing the educt morphology. The fact that some aragonite survives in the dense layers of the shell even after 84 days also points to a slow dissolution rate of aragonite at least in some parts of the shell. New medium-resolution techniques which are capable of mapping the space dependence of dissolution rates in situ (Fischer and Lüttge, 2016) may be able to shed some light on the different behaviour of different shell parts in the future.

\subsection{A palaeontological perspective of our laboratory-based hydrothermal alteration experiments}

The alteration experiments of recent $A$. islandica under controlled laboratory conditions are very important from a palaeontological perspective as they reproduce burial diagenetic conditions. The understanding of the diagenetic processes which control organism hard tissue preservation taphonomic, palaeoecological, and biostratigraphic studies (e.g. Tucker, 1990). Most organisms have hard tissues composed of calcium carbonate, and its metastable form, aragonite, is one of the first biominerals produced at the Precambrian-Cambrian boundary (Runnegar and Bengtson, 1990), as well as one of the most widely used skeletonforming minerals in the Phanerozoic record and today. In fact, aragonitic shells/skeletons are produced by hyolithids, cnidarians, algae, and the widespread and diversified molluscs.

Several studies (Cherns and Wright, 2000; Wright et al., 2003; Wright and Cherns, 2004; James et al., 2005) have underscored that Phanerozoic marine faunas seem to be dominated by calcite-shelled taxa, the labile aragonitic or bimineralic groups being lost during early diagenesis (in the soft sediment, before lithification), potentially causing a serious taphonomic loss. Considering that most molluscs are aragonitic or bimineralic, this loss could be particularly detrimental both for palaeoecological and biostratigraphic studies. However, it has been shown that the mollusc fossil record is not so biased as expected (Harper, 1998; Cherns et al.,
2008). This is due to abundant taphonomic scenarios such as early lithification/hardgrounds, storm plasters, anoxic bottoms, and high sedimentation rates that produce taphonomic windows allowing mollusc preservation (James et al. 2005; Cherns et al., 2008) by controlling organic matter content and residence time in the taphonomically active zone. Even if the factors that control aragonite dissolution are multiple and their interpretation is complex, the laboratory-based hydrothermal alteration experiments performed here offer very interesting insights into the fate of the aragonitic or bimineralic hard tissues that escape early dissolution during shallow burial and have the potential to enter the fossil record. In particular, the resistance of biogenic aragonite to replacement by calcite up to temperature of $175^{\circ} \mathrm{C}$ during hydrothermal alteration offers an additional explanation for the preservation of aragonitic shells/skeletons once they have escaped early dissolution. The results of our experiments neatly explain the observation that the mollusc fossil record is good and allows restoration of evolutionary patterns.

\section{Conclusions}

1. Aragonite crystallite size, porosity, and pore size varies across the cross section of the valve of modern Arctica islandica. While the outer shell layer is highly porous, with pore sizes in the range of a few micrometres, and contains mineral units in the $1-5 \mu \mathrm{m}$ size range, the inner shell layers are characterised by a dense shell structure with small $(1 \mu \mathrm{m})$ mineral units and a very low porosity. The innermost section of the shell is penetrated by elongated pores oriented perpendicular to the shell inner surface. At annual growth lines, $\mathrm{Sr}$ contents are always high relative to shell increments between the growth lines in both pristine and experimentally altered shell samples. The chemistry of the alteration fluid and the duration of the alteration experiment do not exert a major effect on the concentration of $\mathrm{Sr}$ along the growth lines.

2. During hydrothermal alteration at $100^{\circ} \mathrm{C}$ for 28 days, most, but not all, of the biopolymer matrix is destroyed, while shell aragonite and its microstructure are largely preserved.

3. During hydrothermal alteration at $175^{\circ} \mathrm{C}$ for 7 days or more, the biopolymer shell fraction is destroyed, such that pathways for fluid penetration are created. At this temperature and time, shell aragonite is almost completely transformed to calcite.

4. When meteoric solution is used for alteration, newly formed calcite crystal units reach sizes up to $200 \mu \mathrm{m}$, while alteration in burial solution induces the formation of calcite crystals that grow up to $1 \mathrm{~mm}$ in 7 days. We attribute the latter, larger grains to the $\mathrm{Mg}$ content of the 
burial solution, which inhibits calcite nucleation. The formation of fewer nuclei leads to the growth of larger calcite crystals.

5. Geochemical results show that calcite nucleates and a replacement reaction proceeds where the experimental fluid is in contact with the aragonite: at the two shell surfaces, in pores, and at growth lines, which are thin, formerly organic-filled layers.

6. The replacement reaction of bioaragonite to calcite does not proceed at temperatures much lower than $175^{\circ} \mathrm{C}$. At $175^{\circ} \mathrm{C}$, we observe a dormant time of about 4 days during which no XRD-detectable calcite is formed. The replacement reaction then proceeds within 2-3 days to almost completion with small amounts of aragonite still surviving after 84 days in the dense, proximal layer of the shell. The dormant period can be attributed to the low available driving force for calcite nucleation, but further studies dedicated to the nucleation process are necessary.
7. Between two tipping points - one between 50 and $60{ }^{\circ} \mathrm{C}$ (Kitano et al., 1962; Taft, 1967; Ogino et al., 1987; Balthasar and Cusack, 2015) and the other between 160 and $180^{\circ} \mathrm{C}$ (Perdikouri et al., 2011, 2013, this paper) - aragonite appears to precipitate from supersaturated aqueous solutions rather than calcite, such that the hydrothermal treatments of aragonite within this temperature bracket do not yield calcite.

8. The tardy kinetics of aragonite replacement by calcite at temperatures lower than $175^{\circ} \mathrm{C}$ contributes to explaining why aragonitic or bimineralic shells and skeletons have a good potential of preservation and a complete fossil record. 


\section{Appendix A}

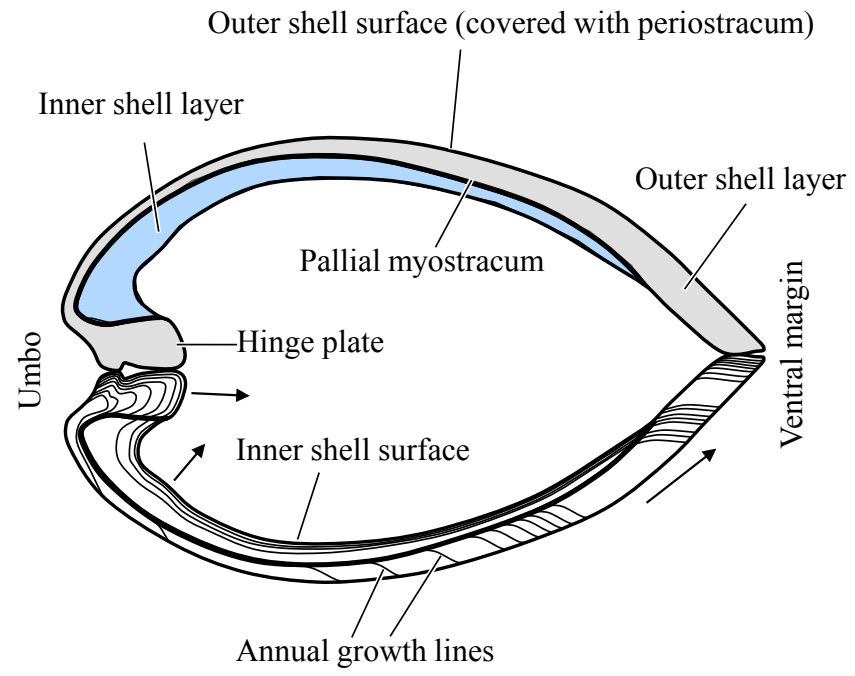

Figure A1. Morphological characteristics of the shell of the bivalve Arctica islandica. A detailed description is given in Schöne (2013).

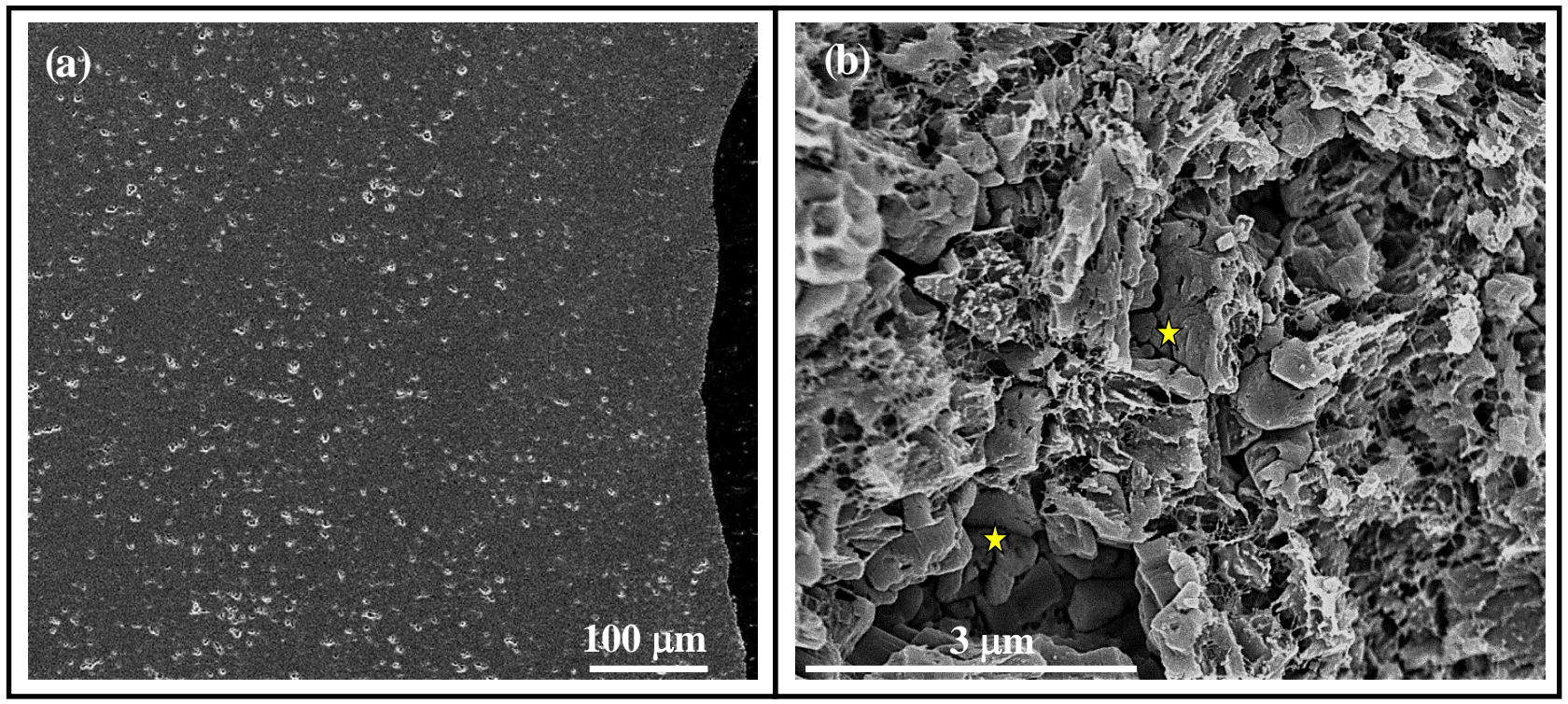

Figure A2. Accumulation of pores (whitish circular features) within the outer shell portions (a). Yellow stars in (b) point to the location of two pores a few nanometres in size. 


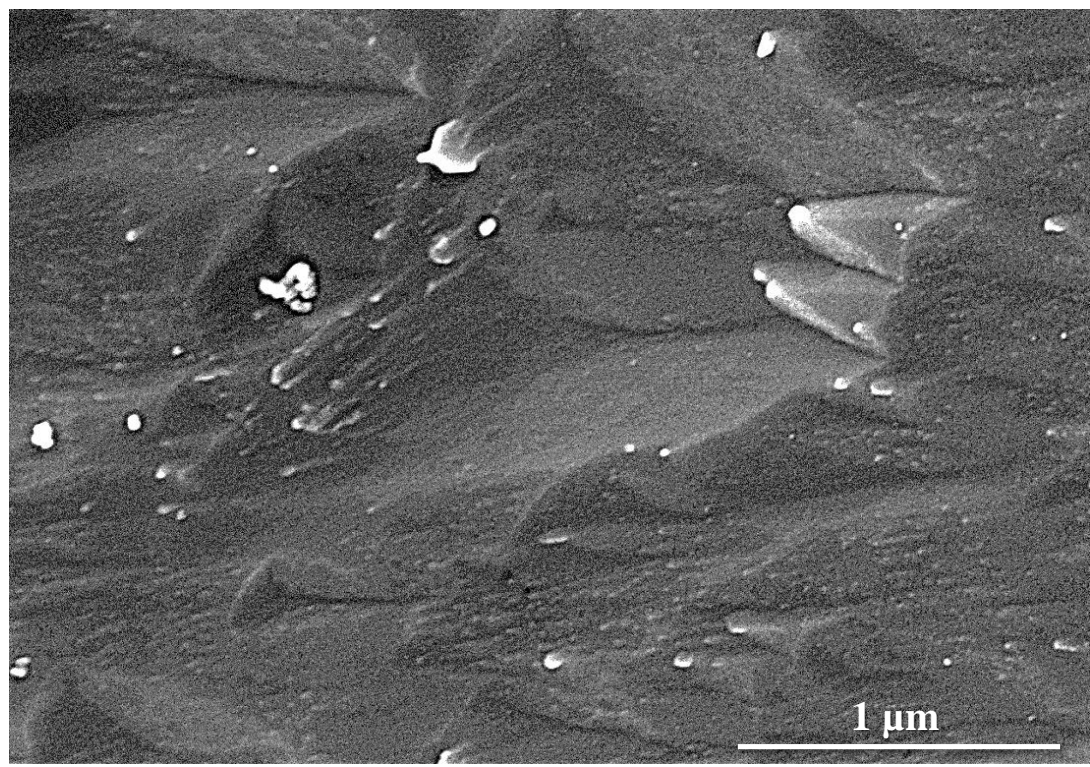

Figure A3. FE-SEM image of microtome-cut, polished, etched and critical-point-dried surface of non-biological aragonite grown from solution.
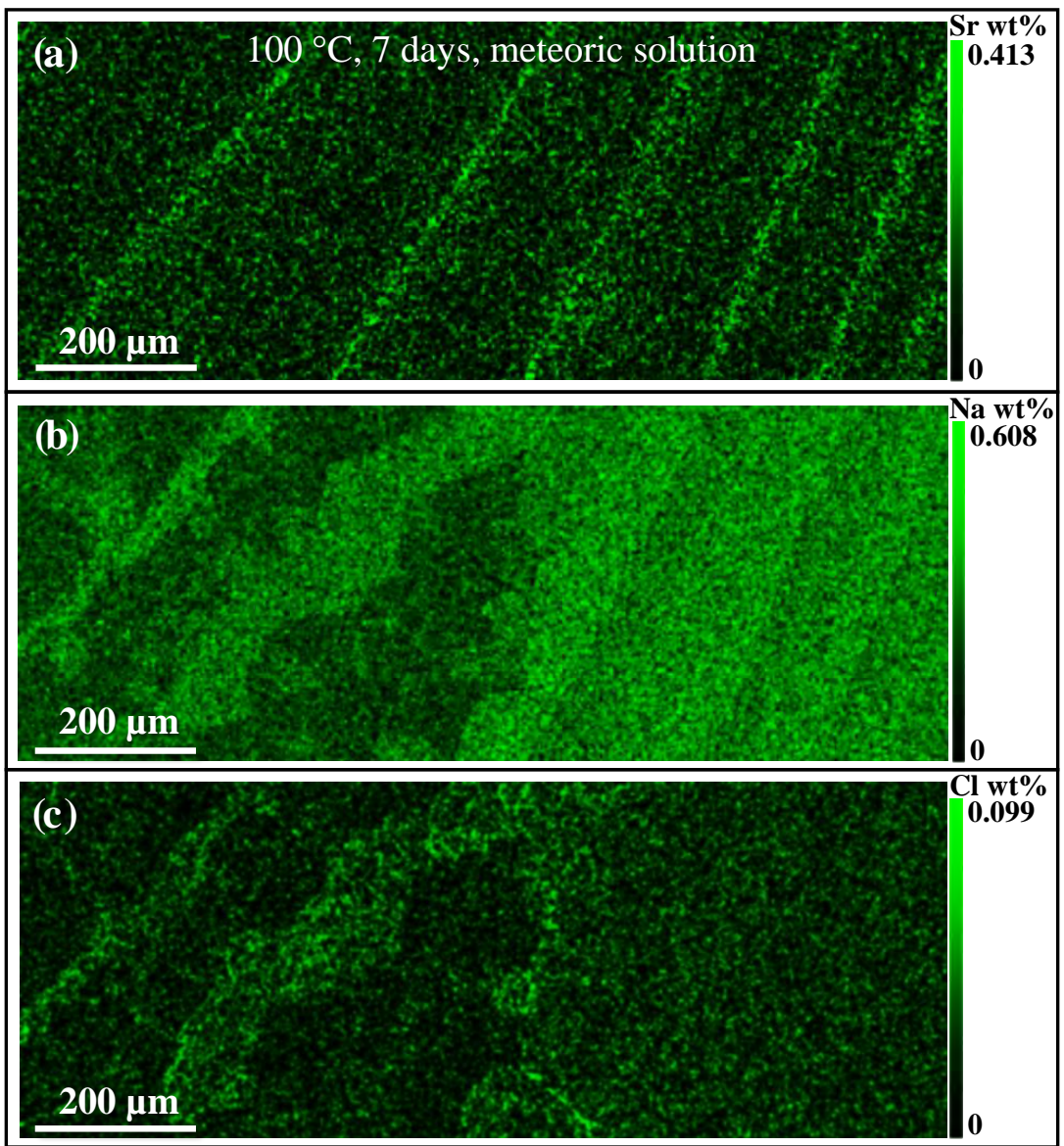

Figure A4. $\mathrm{Sr}^{2+}, \mathrm{Na}^{+}$, and $\mathrm{Cl}^{-}$concentrations along annual growth lines in a hydrothermally altered shell portion of Arctica islandica. The alteration fluid is NaCl-rich, simulating meteoric waters. The degree of fluid infiltration into and through the shell is well traceable with $\mathrm{Na}^{+}$ and $\mathrm{Cl}^{-}$concentrations. Infiltration occurs, in addition through pores, along growth lines that act as conduits for fluid circulation. 


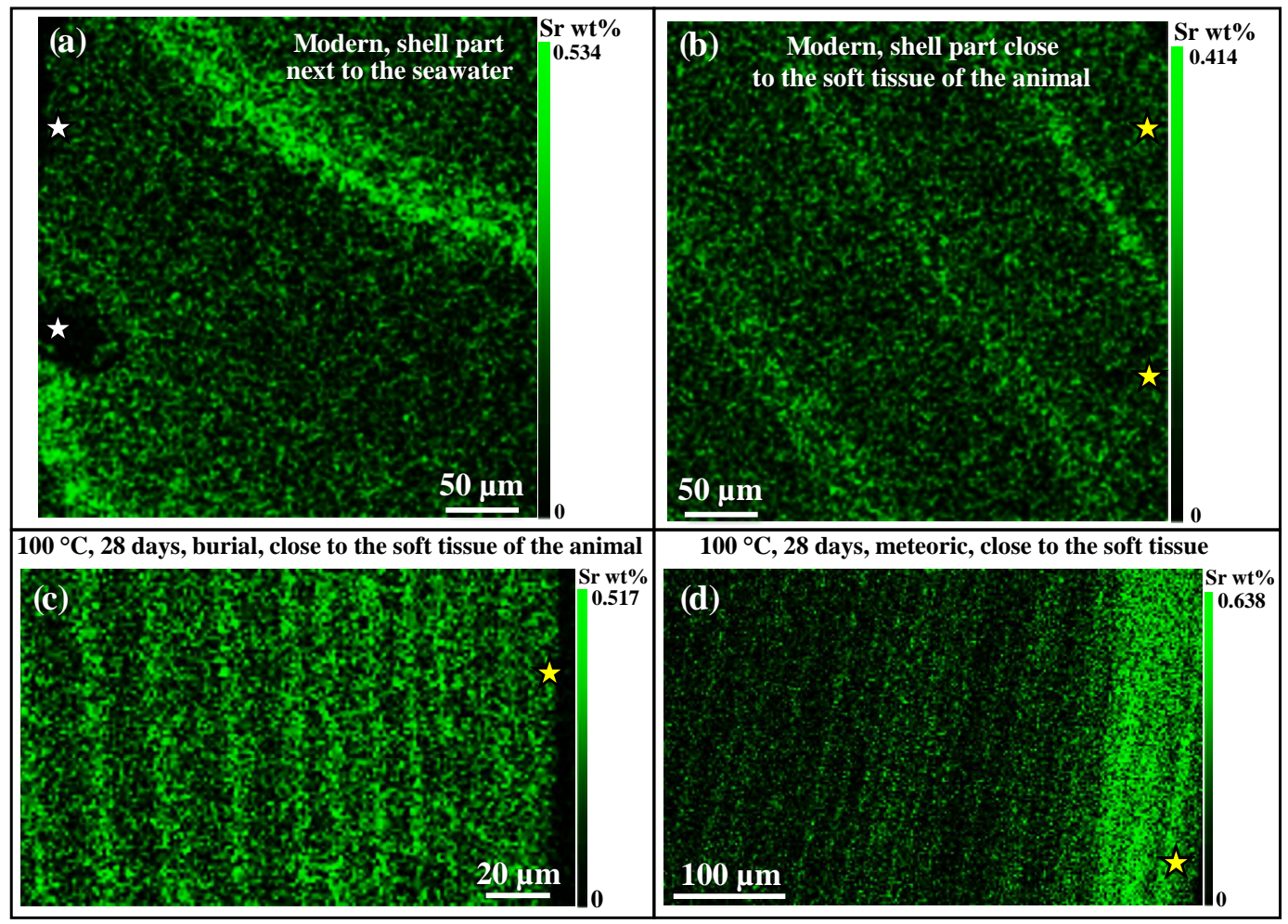

Figure A5. $\mathrm{Sr}^{2+}$ concentrations along annual growth lines in pristine (a, b) and hydrothermally altered (c, d) Arctica islandica shell portions. White stars indicate regions of the outer shell layer, while yellow stars point to the inner shell parts. Fluids enter the shell at its two surfaces (see enrichment in $\mathrm{Sr}^{2+}$ in d) and especially along growth lines. Neither the degree of hydrothermal alteration nor the chemistry of the alteration fluid significantly changes the $\mathrm{Sr}^{2+}$ contents along the growth lines. Maximal values for both pristine and altered samples range between 0.4 and $0.6 \mathrm{wt} \% \mathrm{Sr}$.

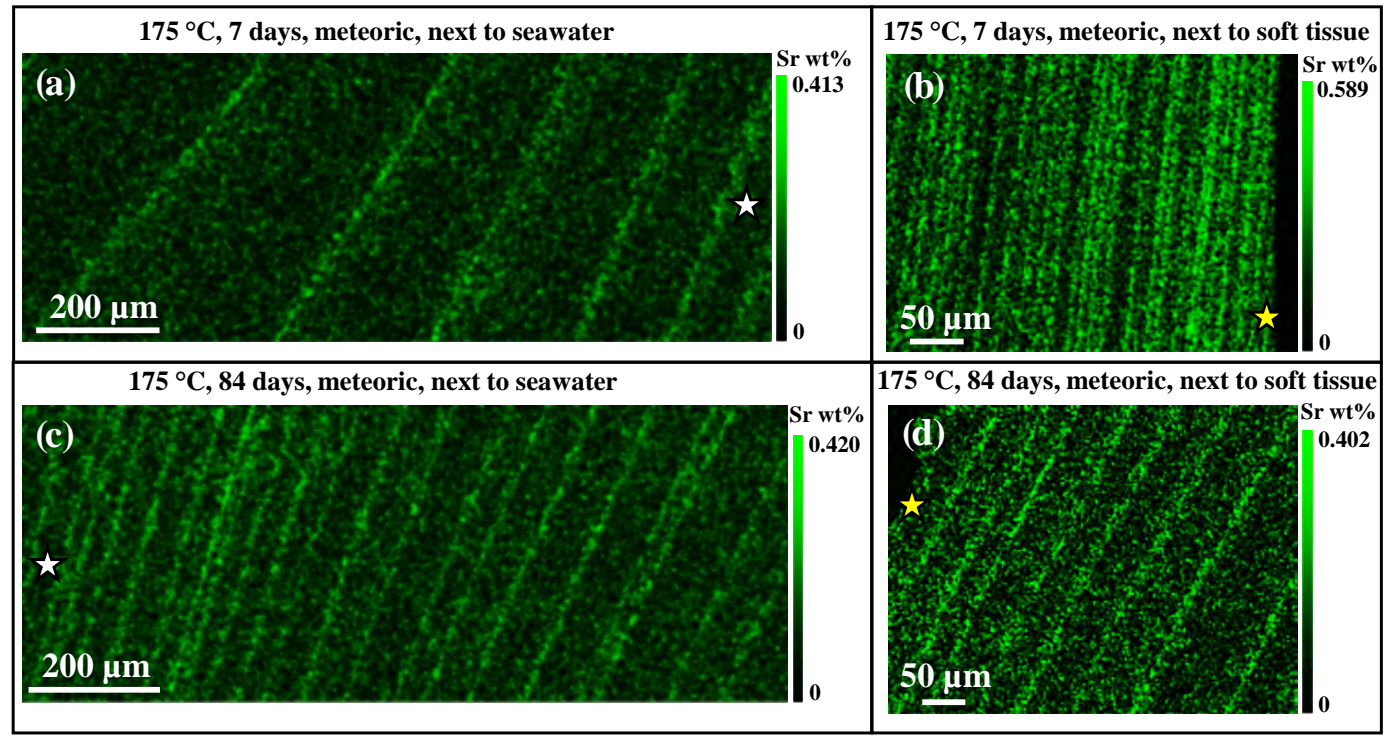

Figure A6. $\mathrm{Sr}^{2+}$ concentrations along annual growth lines in hydrothermally altered Arctica islandica shell portions. Alteration temperature was $175^{\circ} \mathrm{C}$, meteoric water was used as alteration fluid, and the alteration experiments lasted for 7 and 84 days $(\mathbf{a}-\mathbf{b})$. Sr ${ }^{2+}$ concentration scatters for both alteration times around $0.4 \mathrm{wt} \% \mathrm{Sr}^{2+}$ and is similar to the value measured in the pristine Arctica islandica reference samples (see Fig. A5a, b). 


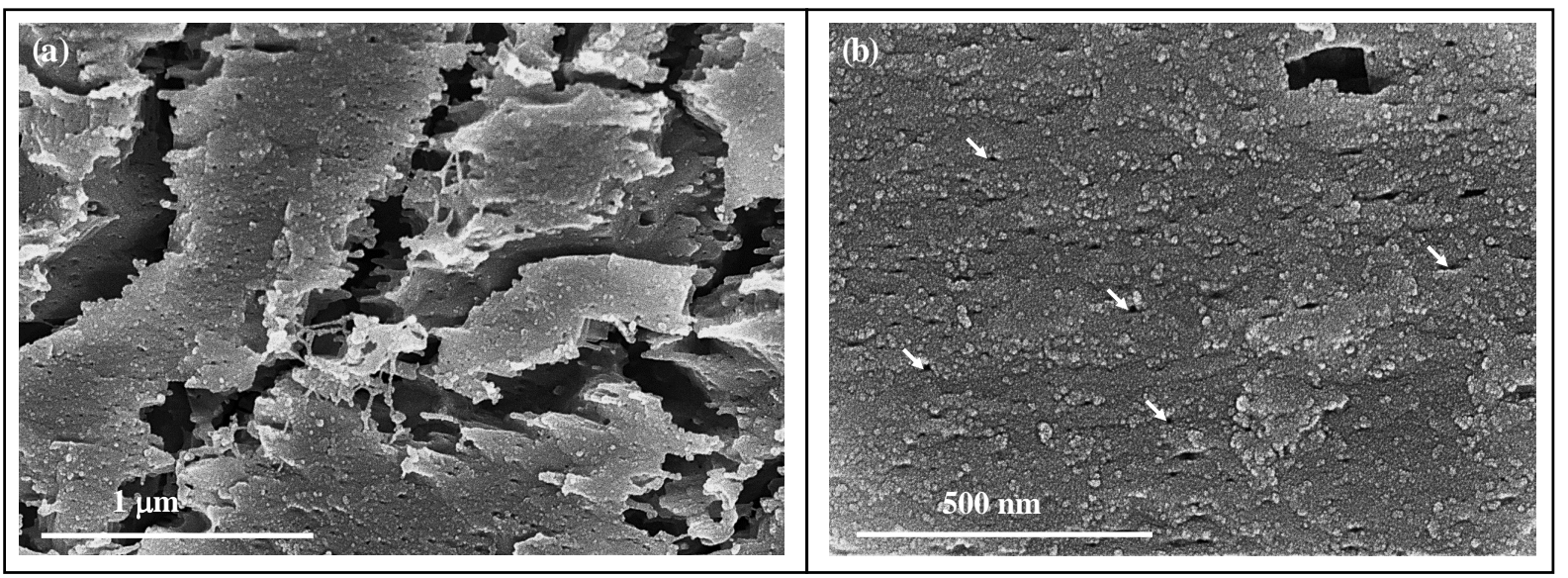

Figure A7. Hydrothermally altered Arctica islandica shell portions. Burial fluid was used for alteration at $100^{\circ} \mathrm{C}$ and for 28 days. (a) As the organic membranes and fibrils are destroyed by alteration, large gaps appear between and numerous minute holes within the mineral units. (b) The biological aragonite of Arctica islandica retains its nanoparticulate appearance after alteration conducted for 28 days at $100{ }^{\circ} \mathrm{C}$.

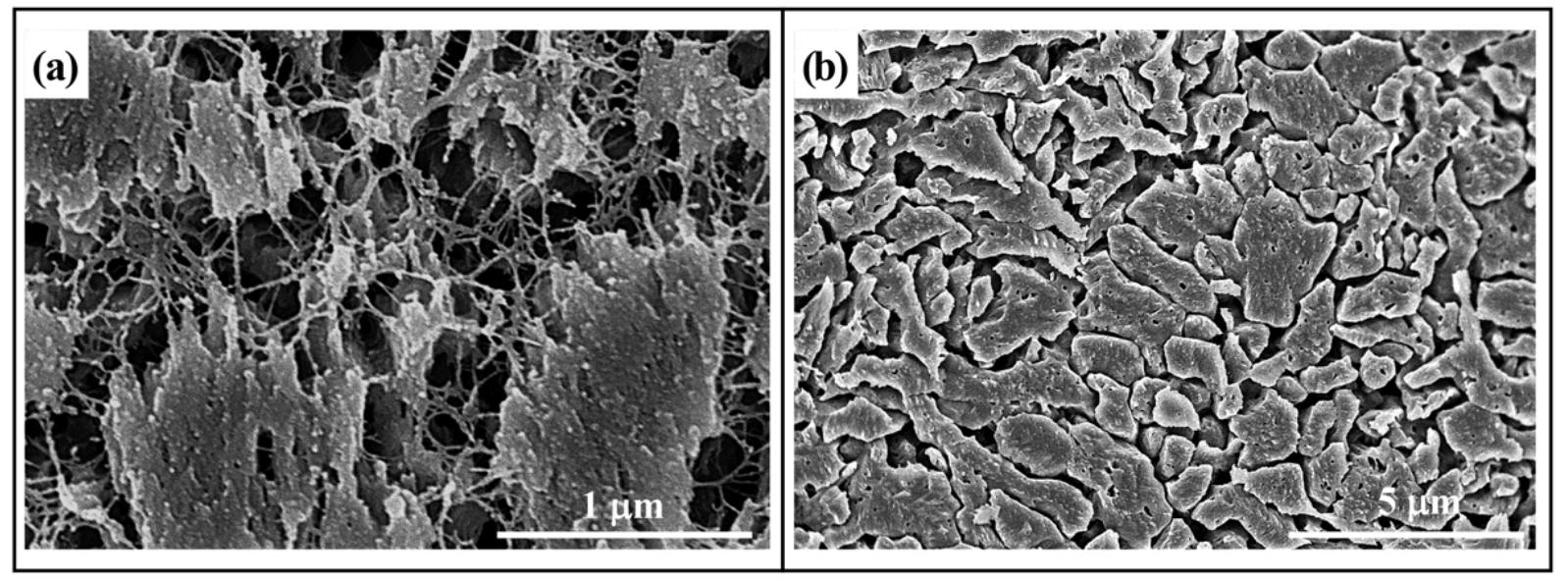

Figure A8. Pristine (a) and hydrothermally altered (b) shell portion of Arctica islandica. Alteration occurred in burial fluid at $175^{\circ} \mathrm{C}$ and lasted for 7 days. Well visible in (a) is the network of biopolymer fibrils between and within pristine aragonite nanoparticles and mineral units. This is destroyed at alteration and numerous voids (b) become visible within the mineral units. 

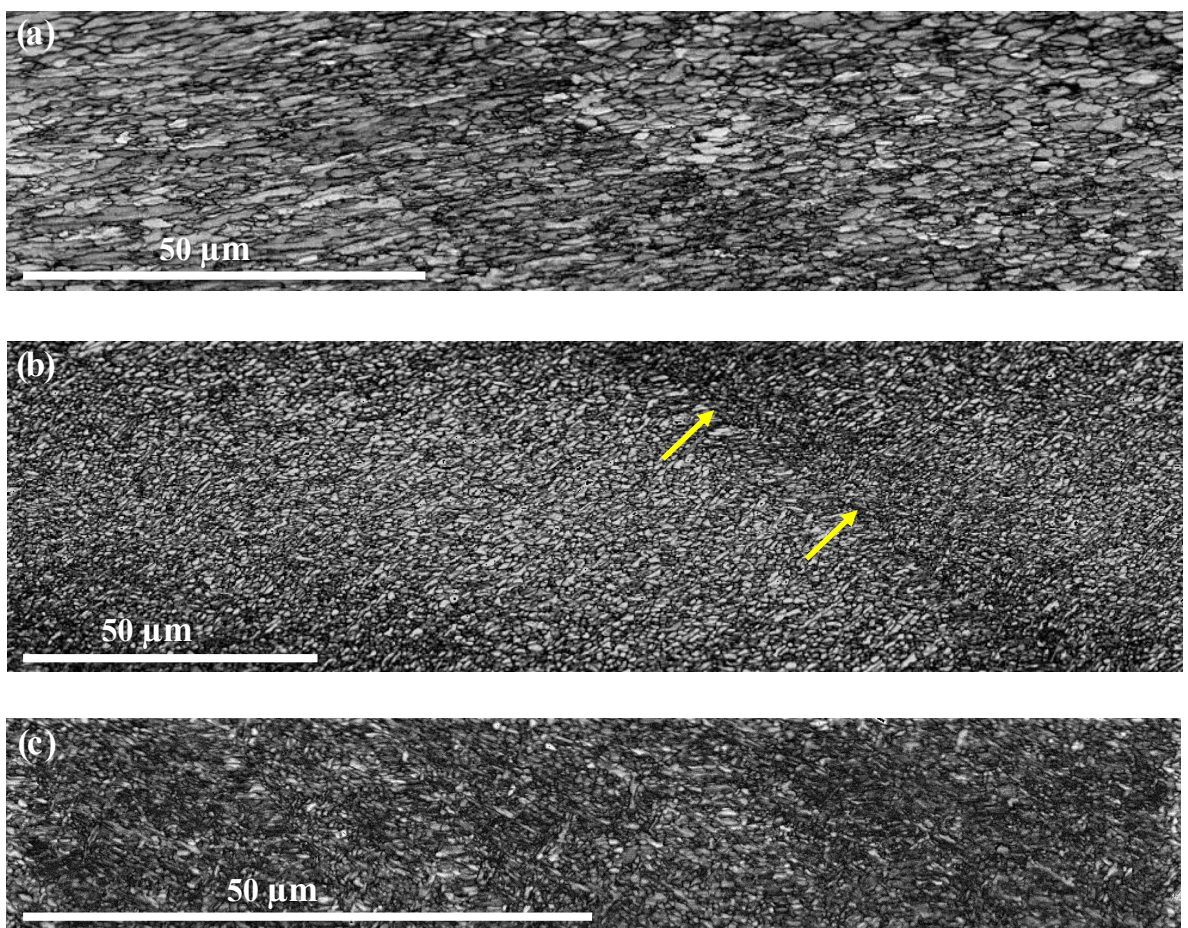

Figure A9. EBSD band contrast images taken along a cross section from different parts of the shell of pristine Arctica islandica. (a) Outer shell layer, (b) central shell section, and (c) inner shell layer. Well visible is the difference in crystallite size. In contrast to the outer shell layer (a), the innermost shell section is highly dense and consists of minute aragonite crystals.
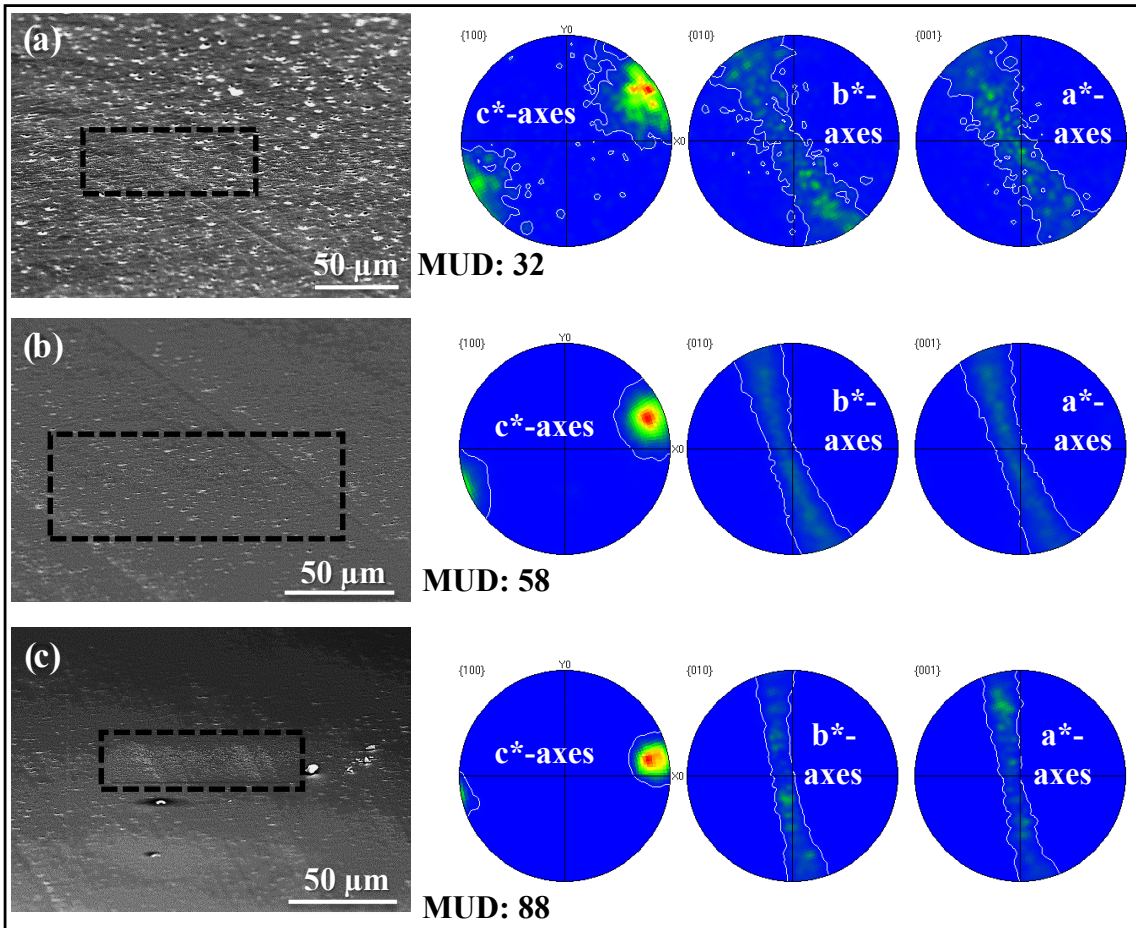

Figure A10. Pole figures obtained from EBSD measurements shown in Fig. A9. Measurements are performed on pristine Arctica islandica. SEM images on the left-hand side indicate the location of EBSD maps: (a) outer shell layer, (b) central shell portion, (c) inner shell layer. The pole figures and MUD values indicate clearly that aragonite co-orientation increases significantly towards innermost shell sections. 


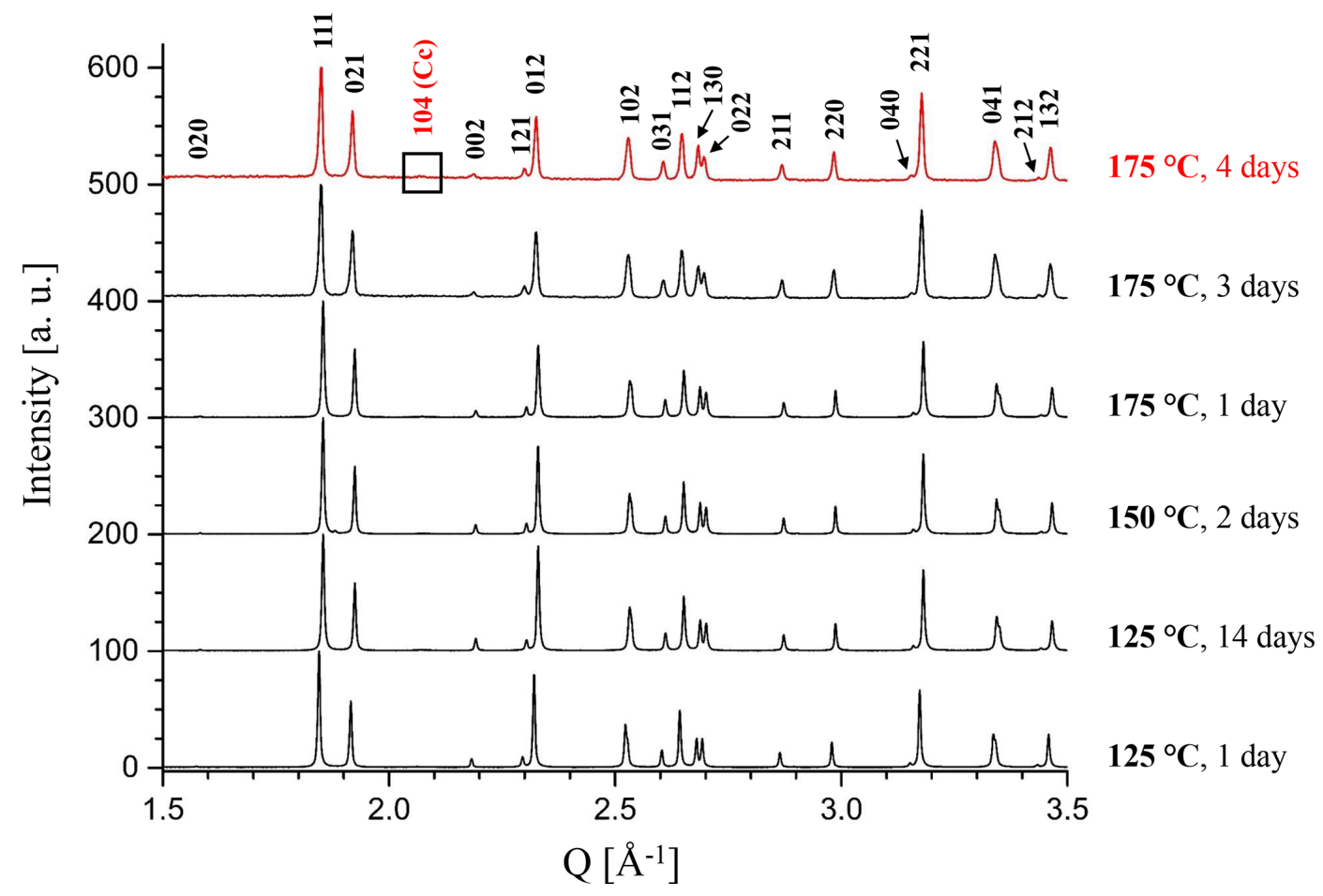

Figure A11. XRD measurements of experimentally altered Arctica islandica samples subjected to alteration temperatures between 125 and $175^{\circ} \mathrm{C}$ for various lengths of time (1, 2, 3, 4 and 14 days). Calcite formation starts at $175^{\circ} \mathrm{C}$ and an alteration time of 4 days. Miller indices for calcite $(\mathrm{Cc})$ are given in red and those for aragonite in black. 


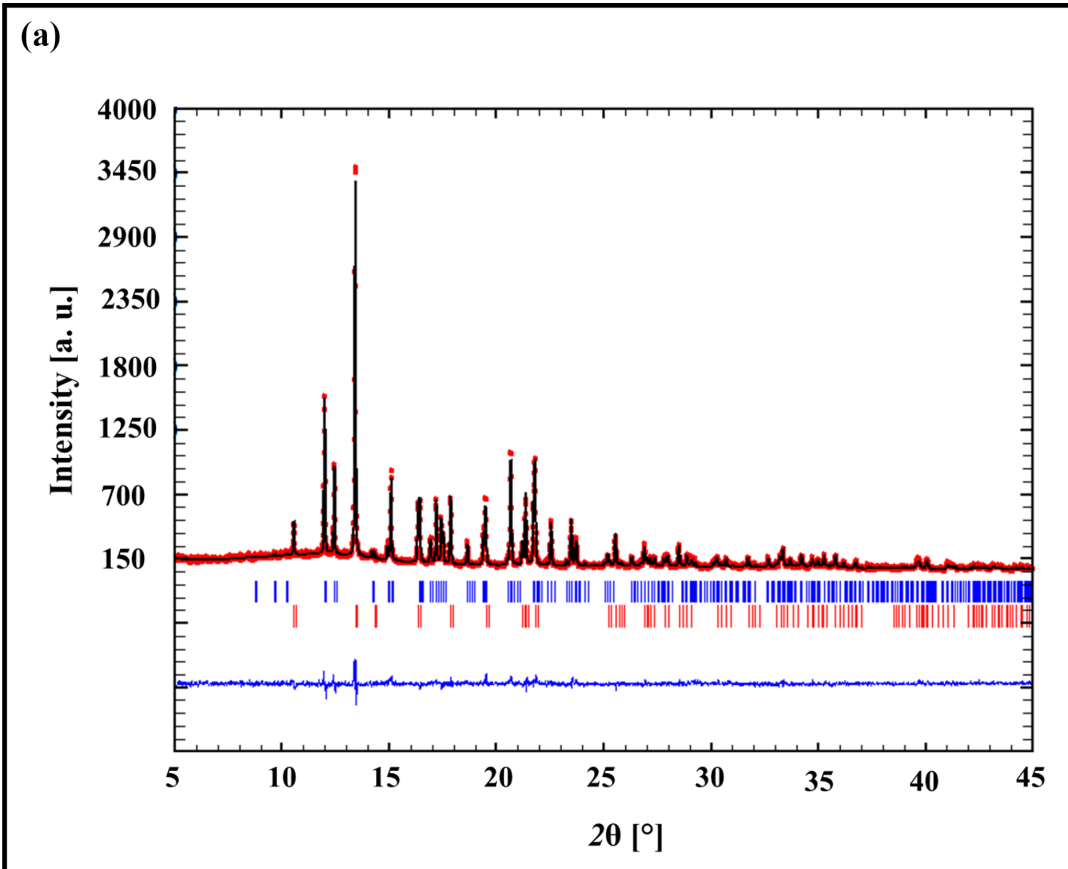

(b)

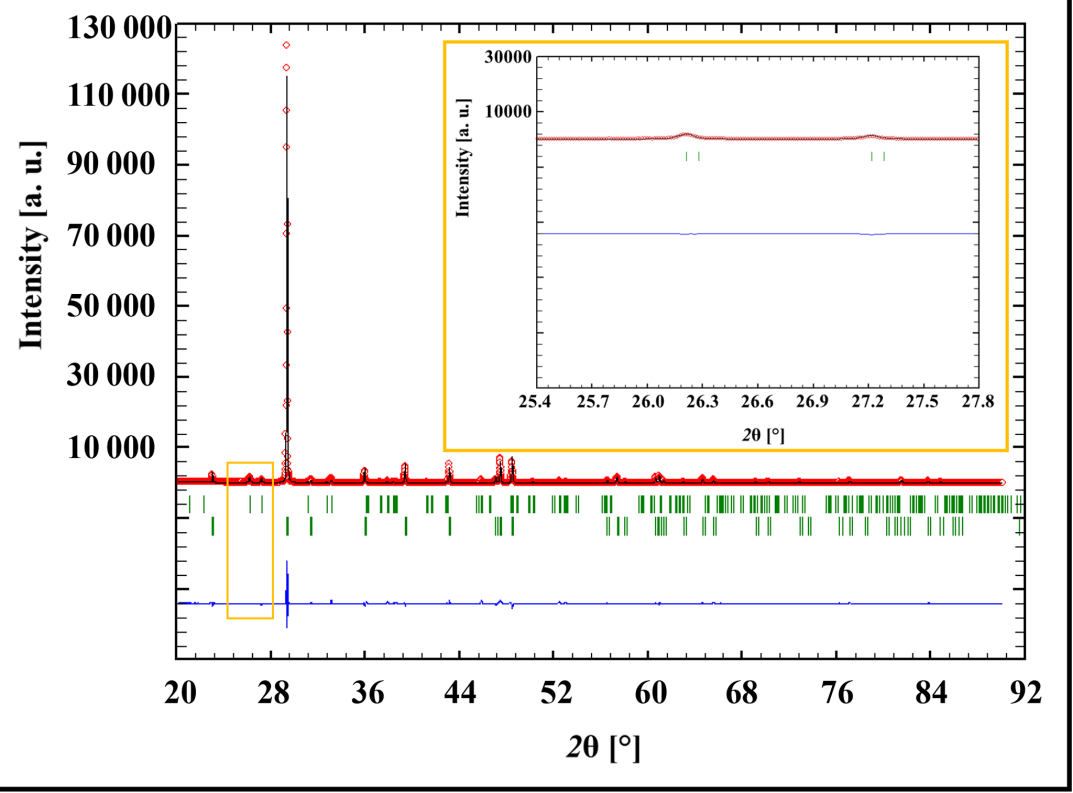

Figure A12. Representative Rietveld plot for the product of the alteration experiment performed at $175^{\circ} \mathrm{C}$ for 6 (a) and 84 days (b) in artificial burial solution measured with $\mathrm{MoK}_{\alpha 1}$ in transmission and with $\mathrm{CuK}_{\alpha 1}$ in reflection, respectively. The diffuse amorphous signal peaking near $12.5^{\circ} 2 \theta$ is due to the Lindemann glass capillary $(\varnothing 0.3 \mathrm{~mm})$ containing the sample. 


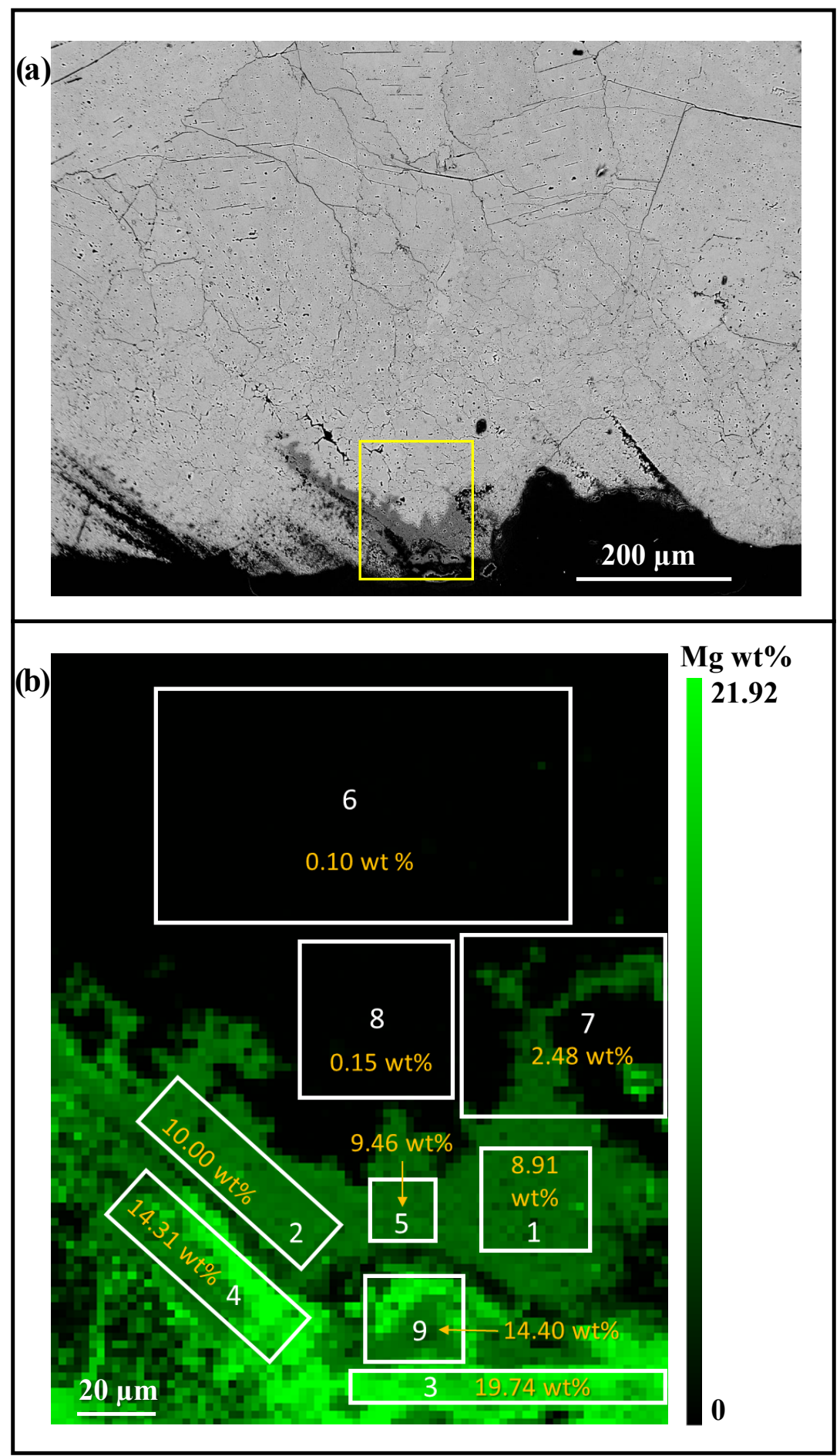

Figure A13. BSE image (a) and Mg concentrations (b) of hydrothermally altered Arctica islandica shell. Alteration occurred in burial solution at $175^{\circ} \mathrm{C}$ for 84 days. The yellow rectangle in (a) indicates the shell portion that is shown in (b) and that was scanned with EPMA. White rectangles in (b) highlight the extent of shell portions that were used for the determination of mean Mg concentrations given in yellow within each rectangle. Note the formation of magnesium-rich carbonates (see Table A1) along the outer rim of the sample. 
Table A1. Electron microprobe analyses (CAMECA SX100 system and procedures described in Goetz et al., 2014) of the original pristine Arctica islandica aragonite and of the treated sample CHA-M046 AI27 B2 near the outer rim of the specimen. The analysed regions are shown in Fig. A13b. The $\left[\mathrm{CO}_{3}\right]$ content is nominal.

\begin{tabular}{|c|c|c|c|c|c|c|c|c|c|c|c|}
\hline \multicolumn{2}{|c|}{ Analysed region } & \multirow{2}{*}{$\begin{array}{r}\mathrm{Mg} \\
8.91\end{array}$} & \multirow{2}{*}{$\begin{array}{r}\mathrm{Ca} \\
25.53\end{array}$} & \multirow{2}{*}{$\begin{array}{c}\text { Mn } \\
0.1\end{array}$} & \multirow{2}{*}{$\begin{array}{r}\mathrm{Na} \\
0.06\end{array}$} & \multirow{2}{*}{$\begin{array}{r}P \\
0.02\end{array}$} & \multirow{2}{*}{$\begin{array}{c}\mathrm{Sr} \\
0.3\end{array}$} & \multirow{2}{*}{$\begin{array}{r}\mathrm{Fe}(\mathrm{II}) \\
0.15\end{array}$} & \multirow{2}{*}{$\begin{array}{r}\text { C } \\
51.58\end{array}$} & \multirow{2}{*}{$\begin{array}{r}\text { O } \\
13.29\end{array}$} & \multirow{2}{*}{$\begin{array}{r}\Sigma \text { cations } \\
\text { (except } \mathrm{P} \text { and } \mathrm{C} \text { ) }\end{array}$} \\
\hline 1 & wt $\%$ & & & & & & & & & & \\
\hline & Formula & 0.3425 & 0.596 & 0.0015 & 0.0025 & 0.0005 & 0.003 & 0.0025 & 3.018 & 1.034 & 0.9480 \\
\hline \multirow[t]{2}{*}{2} & wt $\%$ & 8.91 & 2.53 & 0.1 & 0.06 & 0.02 & 0.3 & 0.14 & 51.33 & 13.29 & \\
\hline & Formu & 0.385 & 0.584 & .0015 & 0.002 & 0.0005 & 0.003 & .0025 & 3.007 & 1.014 & 5 \\
\hline \multirow[t]{2}{*}{3} & wt $\%$ & 19.74 & 11.08 & 0.07 & 0.28 & 0.05 & 0.25 & 0.17 & 54.46 & 13.82 & \\
\hline & Formula & 0.716 & 0.2445 & 0.001 & 0.011 & 0.0015 & 0.0025 & 0.003 & 3.007 & 1.015 & 0.9775 \\
\hline \multirow[t]{2}{*}{4} & wt $\%$ & 14.31 & 18.62 & 0.09 & 0.16 & 0.04 & 0.28 & 0.15 & 52.84 & 13.44 & \\
\hline & Formul & 0.5305 & 0.4285 & 0.0015 & 0.006 & 0.001 & 0.003 & 0.0025 & 3.010 & 1.018 & 0.9720 \\
\hline \multirow[t]{2}{*}{5} & wt $\%$ & 9.46 & 25.49 & 0.1 & 0.06 & 0.02 & 0.29 & 0.16 & 51.29 & 13.05 & \\
\hline & Formula & 0.365 & 0.5965 & 0.002 & 0.0025 & 0.0005 & 0.003 & 0.0025 & 3.01 & 1.019 & 0.9715 \\
\hline \multirow[t]{2}{*}{6} & wt $\%$ & 0.1 & 38.19 & 0.11 & 0.13 & 0.02 & 0.43 & 0.15 & 48.43 & 12.36 & \\
\hline & Formula & 0.004 & 0.948 & 0.002 & 0.0055 & 0.0005 & 0.005 & 0.0025 & 3.011 & 1.022 & 0.9670 \\
\hline \multirow[t]{2}{*}{7} & wt $\%$ & 2.48 & 31.32 & 0.1 & 0.12 & 0.03 & 0.36 & 0.14 & 51.44 & 13.94 & \\
\hline & Formul & 0.095 & 0.751 & 0.0015 & 0.005 & 0.001 & 0.004 & 0.0025 & 3.047 & 1.094 & 0.8590 \\
\hline \multirow[t]{2}{*}{8} & wt $\%$ & 0.15 & 38.26 & 0.11 & 0.12 & 0.02 & 0.43 & 0.15 & 48.37 & 12.32 & \\
\hline & Formula & 0.006 & 0.949 & 0.002 & 0.005 & 0.0005 & 0.005 & 0.0025 & 3.010 & 1.020 & 0.9695 \\
\hline \multirow[t]{2}{*}{9} & wt $\%$ & 14.4 & 18.03 & 0.09 & 0.17 & 0.03 & 0.28 & 0.15 & 53.15 & 13.62 & \\
\hline & Formu & 0.534 & 0.411 & 0.0015 & 0.0065 & 0.001 & 0.003 & 0.0025 & 3.013 & 1.027 & 0.9585 \\
\hline Oris & $\mathrm{wt} \%$ & 0.07 & 39.24 & 0.11 & 0.46 & 0.02 & 0.43 & 0.15 & 47.44 & 11.76 & 0.07 \\
\hline Aragonite & Formula & 0.003 & 0.988 & 0.002 & 0.02 & 0.0005 & 0.005 & 0.0025 & 2.989 & 0.987 & 1.02 \\
\hline
\end{tabular}


Author contributions. Laura A. Casella conducted the scientific work. EBSD measurements were carried out by Erika Griesshaber. Samples were provided by Ann-Christine Ritter, Dorothee Hippler and Elizabeth M. Harper. Laura A. Casella, Vasileios Mavromatis and Martin Dietzel performed hydrothermal alteration experiments. Sample preparation was carried out by Laura A. Casella, Xiaofei Yin and Andreas Ziegler. Dirk Müller and Laura A. Casella carried out EPMA and XRD measurements, respectively. Adrian Immenhauser, Bernd R. Schöne, Lucia Angiolini and Wolfgang W. Schmahl carried out the critical reading of the manuscript and provided help for the completion of the manuscript through fruitful discussions.

Competing interests. The authors declare that they have no conflict of interest.

Acknowledgements. We sincerely thank F. Nindiyasari for her help with biochemical sample preparation, microtome cutting and microtome polishing and $\mathrm{S}$. He for the preparation of samples for XRD measurements. We very much thank J. Pasteris, U. Brand, L. Fernández-Díaz and C. Putnis for their corrections and fruitful discussions. We acknowledge helpful reviews by A. Lüttge and anonymous referees and the editor, L. de Nooijer, which considerably improved the quality of this paper. We thank the German Research Council (DFG) for financial support in the context of the collaborative research initiative CHARON (DFG Forschergruppe 1644, grant agreement number SCHM 930/11-1).

Edited by: L. de Nooije

Reviewed by: A. Lüttge and three anonymous referees

\section{References}

Balthasar, U. and Cusack, M.: Aragonite-calcite seas - Quantifying the gray area, Geology, 43, 99-102, 2015.

Bathurst, R. G. C.: Neomorphic processes in diagenesis, in: Carbonate sediments and their diagenesis, edited by: Bathurst, R. G. C., 7th Edn., Elsevier, Amsterdam, 475-516, 1994.

Berner, R. A.: The role of magnesium in the crystal growth of calcite and aragonite from sea water, Geochim. Cosmochim. Ac., 39, 489-504, 1975.

Bischoff, J. L. and Fyfe, W. S.: Catalysis, inhibition, and the calcitearagonite problem, Part 1, The aragonite-calcite transformation, Am. J. Sci., 266, 65-79, 1968.

Bischoff, J. L.: Kinetics of calcite nucleation: magnesium ion inhibition and ionic strength catalysis, J. Geophys. Res., 73, 33153322, 1968.

Bischoff, J. L.: Temperature controls on aragonite-calcite transformation in aqueous solution, Am. Mineral., 54, 149-155, 1969.

Bischoff, W. D., Mackenzie, F. T., and Bishop, F.C.: Stabilities of synthetic magnesian calcites in aqueous solution: Comparison with biogenic materials, Geochim. Cosmochim. Ac., 51, 14131423, 1987.

Bischoff, W. D., Bertram, M. A., Mackenzie, F. T., and Bishop, F. C.: Diagenetic stabilization pathways of magnesian calcites, Carbonate. Evaporite., 8, 82-89, 1993.
Brand, U.: Strontium isotope diagenesis of biogenic aragonite and low-Mg-calcite, Geochim. Cosmochim. Ac., 55, 505-513, 1991.

Brand, U.: Morphochemical and replacement diagenesis of biogenic carbonates, in: Diagenesis IV, Developments in Sedimentology, edited by: Wolf, K. H. and Chilingarian, G. V., Amsterdam, Elsevier, 51, 217-282, 1994.

Brand, U. and Veizer, J.: Chemical diagenesis of a multicomponent carbonate-system - 1: trace elements, J. Sed. Petrol., 50, 12191236, 1980.

Brand, U. and Veizer, J.: Chemical diagenesis of a multicomponent carbonate system - 2: stable isotopes, J. Sed. Petrol., 51, 987997, 1981.

Brand, U., Logan, A., Hiller, N., and Richardson, J.: Geochemistry of modern brachiopods: applications and implications for oceanography and paleoceanography, Chem. Geol., 198, 305334, 2003.

Brand, U., Azmy, K., Tazawa, J.-I., Sano, H., and Buhl, D..: Hydrothermal diagenesis of paleozoic seamount carbonate components, Chem. Geol., 278, 173-185, 2010.

Brocas, W. M., Reynolds, D. J., Butler, P. G., Richardson, C. A., Scourse, J. D., Ridgway, I. D., and Ramsay, K.: The dog cockle, Glycymeris glycymeris (L.), a new annually-resolved sclerochronological archive for the Irish Sea, Palaeogeogr. Palaeocl., 373, 133-140, 2013.

Butler, P. G., Richardson, C. A., Scourse, J. D., Witbaard, R., Schöne, B. R., Fraser, N. M., Wanamaker Jr., A. D., Bryant, C. L., Harris, I., and Robertson, I.: Accurate increment identification and the spatial extent of the common signal in five Arctica islandica chronologies from the Fladen Ground, northern North Sea, Paleoceanography, 24, PA2210, doi:10.1029/2008PA001715, 2009.

Butler, P. G., Wanamaker Jr., A. D., Scourse, J. D., Richardson, C. A., and Reynolds, D. J.: Variability of marine climate on the North Icelandic Shelf in a 1,357-year proxy archive based on growth increments in the bivalve Arctica islandica, Paleogeogr. Paleocl., 373, 141-151, 2012.

Casey, F. G. S.: Some genera and subgenera, mainly new, of Mesozoic heterodont lamellibranchs, Proc. Malacol. Soc. Lond., 29, 121-176, 1952.

Checa, A. G., Okamoto, T., and Ramírez, J.: Organization pattern of nacre in Pteriidae (Bivalvia: Mollusca) explained by crystal competition, Proc. R. Soc. London Ser. B, 273, 1329-1337, 2006.

Checa, A. G., Ramírez-Rico, J., González-Segura, A., and SánchezNavas, A.: Nacre and false nacre (foliated aragonite) in extant monoplacophorans (= Tryblidiida: Mollusca), Naturwissenschaften, 96, 111-122, 2009.

Cherns, L. and Wrigh, V. P.: Missing molluscs as evidence of largescale, early skeletal aragonite dissolution in a Silurian sea, Geology, 28, 791-794, 2000.

Cherns, L., Wheeley, J. R., and Wrigh, V. P.: Taphonomic windows and molluscan preservation, Palaeogeogr. Palaeocl., 270, 220 229, 2008.

Choudens-Sánchez, V. and Gonzáles, L. A.: Calcite and Aragonite precipitation under controlled instantaneous supersaturation: elucidating the role of $\mathrm{CaCO}_{3}$ saturation state and $\mathrm{Mg} / \mathrm{Ca}$ ratio on calcium carbonate polymorphism, J. Sediment. Res., 79, 363376, 2009.

Crippa, G. and Raineri, G.: The genera Glycymeris, Aequipecten and Arctica, and associated mollusk fauna of the Lower Pleis- 
tocene Arda River section (Northern Italy), Riv. Ital. Paleontol. S., 121, 61-101, 2015.

Crippa, G., Angiolini, L., Bottini, C., Erba, E., Felletti, F. Frigerio, C., Hennissen J. A., Leng, M. J., Petrizzo M. R., Raffi, I., Raineri, and G., Stephenson M. H.: Seasonality fluctuations recorded in fossil bivalves during the early Pleistocene: implications for climate change, Palaeogeogr. Palaeocl., 446, 234-251, 2016.

Cusack, M., Parkinson, D., Freer, A., Pérez-Huerta, A., Fallick, A. E., and Curry, G. B.: Oxygen isotope composition in Modiolus modiolus aragonite in the context of biological and crystallographic control, Mineral. Mag., 72, 569-577, 2008.

Dalbeck, P., England, J., Cusack, M., Lee, M. R., and Fallick, A. E.: Crystallography and chemistry of the calcium carbonate polymorph switch in M. edulis shells, Eur. J. Mineral., 18, 601-609, 2006.

Davis, K. J., Nealson, K. H., and Lüttge, A.: Calcite and dolomite dissolution rates in the context of microbe-mineral surface interactions, Geobiology, 5, 191-205, 2007.

Fabritius, H., Walther, P., and Ziegler, A.: Architecture of the organic matrix in the sternal $\mathrm{CaCO}_{3}$ deposits of Porcellio scaber (Crustacea, Isopoda), J. Struct. Biol., 150, 190-199, 2005.

Fischer, C. and Lüttge, A.: Beyond the conventional understanding of water-rock reactivity, Earth Planet Sc. Lett., 457, 100-105, 2016.

Fyfe, W. S. and Bischoff, J. L: The calcite-aragonite problem, Soc. Econ. Pa., 13, 3-13, 1965.

Gebauer, D. and Cölfen, H.: Prenucleation clusters and nonclassical nucleation, Nano Today, 6, 564-584, 2011.

Gebauer, D., Völkel, A., and Cölfen, H.: Stable prenucleation calcium carbonate Clusters, Science, 322, 1819-1822, 2008.

Goetz, A. J., Griesshaber, E., Abel, R., Fehr, Th., Ruthensteiner, B., and Schmahl, W. W.: Tailored order: The mesocrystalline nature of sea urchin teeth, Acta Biomater., 10, 3885-3898, 2014.

Griesshaber, E., Schmahl, W. W., Singh Ubhi, H., Huber, J., Nindiyasari, F., Maier, B., and Ziegler, A.: Homoepitaxial mesoand microscale crystal co-orientation and organic matrix network structure in Mytilus edulis nacre and calcite, Acta Biomater., 9, 9492-9502, 2013.

Grossman, E. L., Mii, H. S., and Yancey, T. E.: Stable isotopes in Late Pennsylvanian brachiopods fromthe United States: Implications for Carboniferous paleoceanography, Geol. Soc. Am. Bull., 105, 1284-1296, 1993.

Hahn, S., Rodolfo-Metalpa, R., Griesshaber, E., Schmahl, W. W., Buhl, D., Hall-Spencer, J. M., Baggini, C., Fehr, K. T., and Immenhauser, A.: Marine bivalve shell geochemistry and ultrastructure from modern low $\mathrm{pH}$ environments: environmental effect versus experimental bias, Biogeosciences, 9, 1897-1914, 2012.

Hahn, S., Griesshaber, E., Schmahl, W. W., Neuser, R. D., Ritter, A.-C., Hoffmann, R., Buhl, D., Niedermayr, A., Geske, A., and Immenhauser, A.: Exploring aberrant bivalve shell ultrastructure and geochemistry as proxies for past sea water acidification, Sedimentology, 61, 1625-1658, 2014.

Harper, E. M.: The fossil record of bivalve molluscs, in: The adequacy of the fossil record, edited by: Donovan, S. K. and Paul, C. R. C., John Wiley and Sons, Chichester, 243-267, 1998.

Heydari, E.: The role of burial diagenesis in hydrocarbon destruction and $\mathrm{H}_{2} \mathrm{~S}$ accumulation, Upper Jurassic Smackover Formation, Black Creek Field, Mississippi, AAPG Bull., 81, 26-45, 1997.
Immenhauser, A., Nägler, T. F., Steuber, T., and Hippler, D.: A critical assessment of mollusk ${ }^{18} \mathrm{O} /{ }^{16} \mathrm{O}, \mathrm{Mg} / \mathrm{Ca}$, and ${ }^{44} \mathrm{Ca} /{ }^{40} \mathrm{Ca}$ ratios as proxies for Cretaceous seawater temperature seasonality, Palaeogeogr. Palaeocl., 215, 221-237, 2005.

Immenhauser, A., Schöne, B. R., Hoffmann, R., and Niedermayr, A.: Mollusc and brachiopod skeletal hard parts: intricate archives of their marine environment, Sedimentology, 63, 1-59, 2015.

James, N. P., Bone, Y., and Kyser, K. T.: Where has all the aragonite gone? Mineralogy of holocene neritic cool-water carbonates, Southern Australia, J. Sediment. Res., 75, 3, 454-463, 2005.

Jarosch, D. and Heger, G.: Neutron diffraction refinement of the crystal structure of aragonite, Tscher. Miner. Petrog., 35, 127 131, 1986.

Karney, G. B., Butler, P. G., Speller, S., Scourse, J. D., Richardson, C. A., Schröder, M., Highes, G. M., Czernuszka, J. T., and Grovenor, C. R. M.: Characterizing the microstructure of Arctica islandica shells using NanoSIMS and EBSD, Geochem. Geophys. Geosyst., 13, 1-14, 2012.

Kasioptas, A., Perdikouri, C., Putnis, C. V., and Putnis, A.: Pseudomorphic replacement of single calcium carbonate crystals by polycrystalline apatite, Mineral. Mag., 72, 77-80, 2008.

Katz, A.: The interaction of magnesium with calcite during crystal growth at $25-90^{\circ} \mathrm{C}$ and one atmosphere, Geochim. Cosmochim. Ac., 37, 1563-1586, 1973.

Khim, B.-K., Woo, K. S., and Je, J.-G.: Stable isotope profiles of bivalve shells: seasonal temperature variations, latitudinal temperature gradients and biological carbon cycling along the east coast of Korea, Cont. Shelf Res., 20, 843-861, 2000.

Kitano, Y., Park, K., and Hood, D. W.: Pure aragonite synthesis, J. Geophys. Res., 67, 4873-4874, 1962.

Kitano, Y., Yoshioka, S., and Kanamori, N.: The transformation of aragonite to calcite in aqueous solutions, Kaseki, 23/24, 15-25, 1972 (in Japanese).

Korte, C., Kozur, H. W., and Veizer, J.: $\delta^{13} \mathrm{C}$ and $\delta^{18} \mathrm{O}$ values of Triassic brachiopods and carbonate rocks as proxies for coeval seawater and palaeotemperature, Palaegeogr. Palaeocl., 226, 287306, 2005.

Lavoie, D. and Bourque, P.-A.: Marine, burial, and meteoric diagenesis of Early Silurian carbonate ramps, Quebec Appalachians, Canada, J. Sediment. Petrol., 63, 233-247, 1993.

Lebron, I. and Suárez, D. L.: Calcite nucleation and precipitation kinetics as affected by dissolved organic matter at $25^{\circ} \mathrm{C}$ and $\mathrm{pH}>$ 7.5, Geochim. Cosmochim. Ac., 60, 2765-2776, 1996.

Lüttge, A., Zhang, L., and Nealson, K. H.: Mineral surfaces and their implications for microbial attachment: Results from Monte Carlo simulations and direct surface observations, Am. J. Sci., 305, 766-790, 2005.

Maliva, R. G.: Recurrent neomorphic and cement microtextures from different diagenetic environments, Quaternary to late Neogene carbonates, Great Bahama Bank, Sediment. Geol., 97, 1-7, 1995.

Maliva, R. G.: Sceletal neomorphism - quantitative modeling of a two water diagenetic system, Sediment. Geol., 121, 179-190, 1998.

Maliva, R. G., Missimer, T. M., and Dickson, J. A. D.: Sceletal aragonite neomorphism in Plio-Pleistocene sandy limestones and sandstones, Hollywood, Florida, USA, Sediment. Geol., 136 , 147-154, 2000. 
Marchitto, T. M., Jones, G. A., Goodfriend, G. A., and Weidman, C. R.: Precise temporal correlation of Holocene mollusk shells using sclerochronology, Quaternary Res., 53, 236-246, 2000.

Markgraf, S. A. and Reeder, R. J.: High-temperature structure refinements of calcite and Magnesite, Am. Mineral., 70, 590-600, 1985.

Mavromatis, V., Gautier, Q., Bosc, O., and Schott, J.: Kinetics of $\mathrm{Mg}$ partition and $\mathrm{Mg}$ stable isotope fractionation during its incorporation in calcite, Geochim. Cosmochim. Ac., 114, 188-203, 2013.

Metzger, W. J. and Barnard, W. M.: Transformation of aragonite to calcite under hydrothermal conditions, Am. Mineral., 53, 295300, 1968.

Morse, J. W., Mucci, A., and Millero, F. J.: The solubility of calcite and aragonite in seawater of $35 \%$ salinity at $25^{\circ} \mathrm{C}$ and atmospheric pressure, Geochim. Cosmochim. Ac., 44, 85-94, 1980.

Morse, J. W., Wang, Q., and Tsio, M. Y.: Influences of temperature and $\mathrm{Mg}$ : Ca ratio on $\mathrm{CaCO}_{3}$ precipitates from seawater, Geology, 25, 85-87, 1997.

Morse, J. W., Arvidson, R. S., and Lüttge, A.: Calcium carbonate formation and dissolution, Chem. Rev., 107, 342-381, 2007.

Morton, B.: The biology and functional morphology of Arctica islandica (Bivalvia: Arcticidae): a gerontophilic living fossil, Mar. Biol. Res., 7, 540-553, 2011.

Navrotsky, A.: Energetic clues to pathways to biomineralization: Precursors, clusters, and nanoparticles, P. Natl. Acad. Sci. USA, 101, 12096-12101, 2004.

Nindiyasari, F., Fernández-Díaz, L., Griesshaber, E., Astilleros, J. M., Saìnchez-Pastor, N., and Schmahl, W. W.: Influence of gelatin hydrogel porosity on the crystallization of $\mathrm{CaCO}_{3}$, Cryst. Growth Des., 14, 1531-1542, 2014.

Oeschger, R. and Storey, K. B.: Impact of anoxia and hydrogen sulphide on the metabolism of Arctica islandica L. (Bivalvia), J. Exp. Mar. Biol. Ecol., 170, 213-226, 1993.

Ogino, T., Suzuki, T., and Sawada, K.: The formation and transformation mechanism of calcium carbonate in water, Geochim. Cosmochim. Ac., 51, 2757-2767, 1987.

Oomori, T., Kaneshima, H., Maezato, Y., and Kitano, Y.: Distribution coefficient of $\mathrm{Mg}^{2+}$ ions between calcite and solution at 10-50 C, Mar. Chem., 20, 327-336, 1987.

Parkinson, D., Curry, G. B., Cusack, M., Fallick, A. E.: Shell structure, patterns and trends of oxygen and carbon stable isotopes in modern brachiopod shells, Chem. Geol., 219, 193-235, 2005.

Perdikouri, C., Kasioptas, A., Geisler, T., Schmidt, B. C., and Putnis, A.: Experimental study of the aragonite to calcite transition in aqueous solution, Geochim. Cosmochim. Ac., 75, 6211-6224, 2011.

Perdikouri, C., Piazolo, S., Kasioptas, A., Schmidt, B. C., and Putnis, A.: Hydrothermal replacement of Aragonite by Calcite: interplay between replacement, fracturing and growth, Eur. J. Mineral., 25, 123-136, 2013.

Plummer, L. N. and Mackenzie, F. T.: Predicting mineral solubility from rate data; application to the dissolution of magnesian calcites, Am. J. Sci., 274, 61-83, 1974.

Plummer, L. N. and Busenberg, E.: The solubilities of calcite, aragonite and vaterite in $\mathrm{CO}_{2}-\mathrm{H}_{2} \mathrm{O}$ solutions between 0 and $90^{\circ} \mathrm{C}$, and an evaluation of the aqueous model for the system $\mathrm{CaCO}_{3}$ $\mathrm{CO}_{2}-\mathrm{H}_{2} \mathrm{O}$, Geochim. Cosmochim. Ac., 46, 1011-1040, 1982.
Pollok, K., Putnis, C. V., and Putnis, A.: Mineral replacement reactions in solid solution-aqueous solution systems: volume changes, reaction paths and end-points using the example of model salt systems, Am. J. Sci., 311, 211-236, 2011.

Pouchou, J. L. and Pichoir, F.: A new model for quantitative Xray microanalysis, part I: Application to the analysis of homogeneous samples, Rech. Aérosp., 3, 13-38, 1984.

Prior, D. J., Boyle, A. P., Brenker, F., Cheadle, M. C., Day, A., Lopez, G., Peruzzo, L., Potts, G J., Reddy, S., Spiess, R., Timms, N. E., Trimby, P., Wheeler, J., and Zetterström, L.: The application of electron backscatter diffraction and orientation contrast imaging in the SEM to textural problems in rocks, Am. Mineral., 84, 1741-1759, 1999.

Putnis, A. and Austrheim, H.: Fluid-induced processes: metasomatism and Metamorphism, Geofluids, 10, 254-269, 2010.

Putnis, A. and Putnis, C. V.: The mechanism of re-equilibration of solids in the presence of a fluid phase, J. Solid State Chem., 180, 1783-1786, 2007.

Radha, A. V. and Navrotsky, A.: Thermodynamics of carbonates, Rev. Mineral. Geochem., 77, 73-121, 2013.

Radha, A. V., Forbes, T. Z., Killian, C. E., Gilbert, P. U. P. A., and Navrotsky, A.: Transformation and crystallization energetic of synthetic and biogenic amorphous calcium Carbonate, PNAS, 107, 16438-16443, 2010.

Raffi, S.: The significance of marine boreal molluscs in the Early Pleistocene faunas of the Mediterranean area, Palaeogeogr. Palaeocl., 52, 267-289, 1986.

Randle, V. and Engler, O.: Introduction to texture analysis, CRC Press, Amsterdam, 2000.

Redfern, S. A. T., Salje, E., and Navrotsky, A.: High-temperature enthalpy at the orientational order-disorder transition in calcite: implications for the calcite/aragonite phase equilibrium, Contrib. Mineral. Petr., 101, 479-484, 1989.

Richardson, C. A.: Molluscs as archives of environmental change, Oceanogr. Mar. Biol., 39, 103-164, 2001.

Riechelmann, S., Mavromatis, V., Buhl, D., Dietzel, M., Eisenhauer, A., and Immenhauser, A.: Impact of diagenetic alteration on brachiopod shell magnesium isotope $\left(\delta^{26} \mathrm{Mg}\right)$ signatures: Experimental versus field data, Chem. Geol., 440, 191-206, 2016.

Ritter, A.-C., Mavromatis, V., Dietzel, M., Wiethoff, F., Griesshaber, E., Casella, L. A., Schmahl, W. W., Koelen, J., Neuser, R. D., Leis, A., Buhl, D., Niedermayr, A., Bernasconi, S. M., and Immenhauser, A.: Exploring the impact of diagenesis on (isotope)geochemical and microstructural alteration features in biogenic aragonite, Sedimentology, doi:10.1111/sed.12356, 2017.

Rodríguez-Carvajal, J.: Recent Developments of the Program FULLPROF, in Commission on Powder Diffraction (IUCr), Newsletter, 26, 12-19, 2001.

Runnegar, B. and Bengtson, S.: Origin of Hard Pars - Early Skeletal Fossils, in: Palaeobiology A synthesis, edited by: Briggs, D. E. G. and Crowther, P. R., Blackwell Scientific Publications, Oxford, 24-29, 1990.

Saldi, G. D., Jordan, G., Schott, J., and Oelkers, E. H.: Magnesite growth rates as a function of temperature and saturation state, Geochim. Cosmochim. Ac., 73, 5646-5657, 2009.

Saldi, G. D., Schott, J., Pokrovsky, O. S., Gautier, Q., and Oelkers, E. H.: An experimental study of magnesite precipitation rates at neutral to alkaline conditions and $100-200^{\circ} \mathrm{C}$ as a func- 
tion of $\mathrm{pH}$, aqueous solution composition and chemical affinity, Geochim. Cosmochim. Ac., 83, 93-109, 2012.

Schmidt, N. H. and Olesen, N. O.: Computer-aided determination of crystal-lattice orientation from electron channeling patterns in the SEM, Can. Mineral., 27, 15-22, 1989.

Schöne, B.: Arctica islandica (Bivalvia): A unique paleoenvironmental archive of the northern North Atlantic Ocean, Global Planet. Change, 111, 199-225, 2013.

Schöne, B. R. and Fiebig, J.: Seasonality in the North Sea during the Allerod and Late Medieval Climate Optimum using bivalve sclerochronology, Int. J. Earth Sci., 98, 83-98, 2009.

Schöne, B. R. and Surge, D. M.: Bivalve sclerochronology and geochemistry, in: Treatise of Invertebrate Paleontology, edited by: Selden, P. A., Treatise Online 46, Part N Revised, Mollusca (Bivalvia), vol. 1, chapter 14, 1-24, 2012.

Schöne, B. R., Freyre Castro, A. D., Fiebig, J., Houk, S. D., Oschmann, W., and Kröncke, I.: Sea surface water temperatures over the period 1884-1983 reconstructed from oxygen isotope ratios of a bivalve mollusk shell (Arctica islandica, southern North Sea), Palaeogeogr. Palaeocl., 212, 215-232, 2004.

Schöne, B. R., Pfeiffer, M., Pohlmann, T., and Siegismund, F.: A seasonally resolved bottom-water temperature record for the period as 1866-2002 based on shells of Arctica islandica (Mollusca, North Sea), Int. J. Climatol., 25, 947-962, 2005 a.

Schöne, B. R., Houk, S. D., Freyre Castro, A. D., Fiebig, J., Kröncke, I., Dreyer, W., Gosselck, F., and Oschmann, W.: Daily growth rates in shells of Arctica islandica: assessing subseasonal environmental controls on a long-lived bivalve mollusc, Palaios, 20, 78-92, 2005b.

Scourse, J., Richardson, C., Forsythe, G., Harris, I., Heinemeier, J., Fraser, N., Briffa, K., and Jones, P.: First cross-matched floating chronology from the marine fossil record: data from growth lines of the long-lived bivalve mollusc Arctica islandica, The Holocene, 16, 967-974, 2006.

Shirai, K., Schöne, B. R., Miyaji, T., Radarmacher, P., Krause Jr., R. A., and Tanabe, K.: Assessment of the mechanism of elemental incorporation into bivalve shells (Arctica islandica) based on elemental distribution at the microstructural scale, Geochim. Cosmochim. Ac., 126, 307-320, 2014.

Strahl, J., Dringen, R., Schmidt, M. M., Hardenberg, S., and Abele, D.: Metabolic and physiological responses in tissues of the longlived bivalve Arctica islandica to oxygen deficiency, Comp. Biochem. Physiol. A, 158, 513-519, 2011.

Swart, P. K.: The geochemistry of carbonate diagenesis: The past, present and future, Sedimentology, 62, 1233-1304, 2015.

Taft, W. H.: Physical chemistry of formation of carbonates, Dev. Sediment., 9, 151-167, 1967.

Taylor, A. C.: Burrowing behavior and anaerobiosis in the bivalve Arctica islandica (L.), J. Mar. Biol. Assoc. UK, 56, 95-109, 1976.

Titschak, J., Radtke, U., and Freiwald, A.: Dating and characterization of polymorphic transformation of aragonite to calcite in pleistocene bivalves from Rodes (Greece) by combined shell microstructure, stable isotope, and electron spin resonance, J. Sediment. Res., 79, 332-346, 2009.
Tucker, M. E.: Diagenesis, in: Palaeobiology A synthesis, edited by: Briggs, D. E. G. and Crowther, P. R., Blackwell Scientific Publications, Oxford, 247-250, 1990.

Ullmann, C. V. and Korte, C.: Diagenetic alteration in low-Mg calcite from macrofossils: A review, Geol. Quart., 59, 3-20, 2015.

Walter, L. M. and Morse, J. W.: Magnesian calcite stabilities: A reevaluation, Geochim. Cosmochim. Ac., 48, 1059-1069, 1984.

Wanamaker Jr., A., Kreutz, K., Schöne, B., Pettigrew, N., Borns, H., Introne, D., Belknap, D., Maasch, K., and Feindel, S.: Coupled North Atlantic slope water forcing on Gulf of Maine temperatures over the past millennium, Clim. Dynam., 31, 183-194, 2008.

Wanamaker Jr., A. D., Kreutz, K. J., Schöne, B. R., and Introne, D. S.: Gulf of Main shells reveal changes in seawater temperature seasonality during the Medieval Climate Anomaly and the Little Ice Age, Paleogeogr. Paleocl., 302, 43-51, 2011.

Weidmann, C. R., Jones, G. A., and Lohmann, K.: The long-lived mollusc Arctica islandica: a new paleoocenographic tool for the reconstruction of bottom temperatures for the continental shelves of the northern Northern Atlantic Ocean, J. Geophys. Res.-Oceans, 99, 18305-18314, 1994.

Witbaard, R. and Bergman, M. J. N.: The distribution and population structure of the bivalve Arctica islandica L. in the North Sea: What possible factors are involved?, J. Sea Res., 50, 11-25, 2003.

Wright, V. P. and Cherns, L.: Are there "black holes" in carbonate deposystems?, Geol. Acta, 2, 285-290, 2004.

Wright, V. P., Cherns, L., and Hodges, P.: Missing molluscs: Field testing taphonomic loss in the Mesozoic through early largescale aragonite dissolution, Geology, 31, 211-214, 2003.

Xia, F., Brugger, J., Chen, G., Ngothai, Y., O’Neill, B., Putnis, A., and Pring, A.: Mechanism and kinetics of pseudomorphic mineral replacement reactions: a case study of the replacement of pentlandite by violarite, Geochim. Cosmochim. Ac., 73, 19451969, 2009.

Sass, E., Morse, J. W., and Millero, F. J.: Dependence of the values of calcite and aragonite thermodynamic solubility products on ionic models, Am. J. Sci., 283, 218-229, 1983.

Sun, W., Jayaramana, S., Chen, W., Persson, K. A., and Cedera, G.: Nucleation of metastable aragonite $\mathrm{CaCO}_{3}$ in seawater, PNAS, 112, 3199-3204, 2015.

Yoshioka, S., Ohde, S., Kitano, Y., and Kanamori, N.: Behaviour of magnesium and strontium during the transformation of coral aragonite to calcite in aquatic environments, Mar. Chem., 18, 3548, 1986.

Zeppenfeld, K.: Experimentelle Untersuchungen über den Einfluss einiger Zwei-und Dreiwertiger Metallkationen auf die Bildung und das Wachstum von $\mathrm{CaCO}_{3}$ : Experimental Study of the Influence of Some Divalent and Trivalent Metal Cations on Nucleation and Growth of $\mathrm{CaCO}_{3}$, Chem. Erde-Geochem., 63, 264280, 2003. 